\title{
1 Fluid-induced breakdown of white mica controls 2 nitrogen transfer during fluid-rock interaction in 3 subduction zones
}

6 Ralf Halama ${ }^{1, *}$, Gray E. Bebout ${ }^{2}$, Horst R. Marschall ${ }^{3,4}$, Timm John $^{5}$

$8{ }^{1}$ School of Geography, Geology and the Environment, Keele University, Keele, ST5 5BG, United 9 Kingdom

$10{ }^{2}$ Department of Earth and Environmental Sciences, Lehigh University, 1 West Packer Avenue, 11 Bethlehem, Pennsylvania 18015, USA

$12{ }^{3}$ Department of Geology and Geophysics, Woods Hole Oceanographic Institution, 266 Woods Hole 13 Rd., Woods Hole, Massachusetts 02543, USA

$14{ }^{4}$ Goethe-Universität Frankfurt, Institut für Geowissenschaften, Altenhöferallee 1, 60348 Frankfurt 15 am Main, Germany

$16{ }^{5}$ Institut für Geologische Wissenschaften, Freie Universität Berlin, Malteserstr. 74-100, 12249

17 Berlin, Germany

$19 *$ Corresponding author contact information:

20 Ralf Halama

21 School of Geography, Geology and the Environment

22 Keele University, Keele, ST5 5BG, United Kingdom

23 E-mail: r.halama@keele.ac.uk

24 Tel: $+44-1782-734960$

25

26 Word count: 6310

27 Revised version, submitted to International Geology Review 09/2016

28 


\section{Abstract}

In order to determine the effects of fluid-rock interaction on nitrogen elemental and isotopic systematics in high-pressure metamorphic rocks, we investigated three different profiles representing three distinct scenarios of metasomatic overprinting. A profile from the Chinese Tianshan (ultra)high pressure - low temperature metamorphic belt represents a prograde, fluidinduced blueschist-eclogite transformation. This profile shows a systematic decrease in $\mathrm{N}$ concentrations from the host blueschist $(\sim 26 \mu \mathrm{g} / \mathrm{g})$ via a blueschist-eclogite transition zone (19-23 $\mu \mathrm{g} / \mathrm{g})$ and an eclogitic selvage $(12-16 \mu \mathrm{g} / \mathrm{g})$ towards the former fluid pathway. Eclogites and blueschists show only a small variation in $\delta^{15} \mathrm{~N}_{\text {air }}(+2.1 \pm 0.3 \%$ ), but the systematic trend with distance is consistent with a batch devolatilization process. A second profile from the Tianshan represents a retrograde eclogite-blueschist transition. It shows increasing, but more scattered $\mathrm{N}$ concentrations from the eclogite towards the blueschist and an unsystematic variation in $\delta^{15} \mathrm{~N}$ values $\left(\delta^{15} \mathrm{~N}=+1.0\right.$ to $+5.4 \%$ ). A third profile from the high- $P / T$ metamorphic basement complex of the Southern Armorican Massif (Vendée, France) comprises a sequence from an eclogite lens via retrogressed eclogite and amphibolite into metasedimentary country rock gneisses. Metasedimentary gneisses have high $\mathrm{N}$ contents $(14-52 \mu \mathrm{g} / \mathrm{g})$ and positive $\delta^{15} \mathrm{~N}$ values (+2.9 to $+5.8 \%$ ), and $\mathrm{N}$ concentrations become lower away from the contact with $11-24 \mu \mathrm{g} / \mathrm{g}$ for the amphibolites, 10-14 $\mu \mathrm{g} / \mathrm{g}$ for the retrogressed eclogite, and 2.1-3.6 $\mu \mathrm{g} / \mathrm{g}$ for the pristine eclogite, which also has the lightest $\mathrm{N}$ isotopic compositions $\left(\delta^{15} \mathrm{~N}=+2.1\right.$ to $\left.+3.6 \%\right)$.

Overall, geochemical correlations demonstrate that phengitic white mica is the major host of $\mathrm{N}$ in metamorphosed mafic rocks. During fluid-induced metamorphic overprint, both abundances and isotopic composition of $\mathrm{N}$ are controlled by the stability and presence of white mica. Phengite breakdown in high- $P / T$ metamorphic rocks can liberate significant amounts of $\mathrm{N}$ into the fluid. Due to the sensitivity of the $\mathrm{N}$ isotope system to a sedimentary signature, it can be used to trace the extent of $\mathrm{N}$ transport during metasomatic processes. The Vendée profile demonstrates that this process occurs over several tens of meters and affects both $\mathrm{N}$ concentrations and $\mathrm{N}$ isotopic

\section{Keywords:}

59 Nitrogen, $\mathrm{N}$ isotopes, white mica, fluid-rock interaction, subduction, high-pressure metamorphic rocks 


\section{Introduction}

62

63

64

65

66

67

68

69

70

71

Understanding the processes that affect both elemental concentrations as well as isotopic signatures in subducting rocks are of fundamental importance for the assessment of subduction zone cycling of elements (e.g., Bebout 2007, 2014; Marschall et al. 2007a; Halama et al. 2011; John et al. 2004, 2011; Spandler and Pirard 2013; Konrad-Schmolke and Halama 2014; Bebout and Penniston-Dorland 2016). Elemental and isotopic fractionation during subduction-zone metamorphism and metasomatism influences the balance of input and output in subduction zones and the geochemical signatures transported into the deep mantle beyond the arc, potentially resurfacing via plume-related magmatism. Metamorphic rock sequences that record the successive advance of a metamorphic/metasomatic process provide a valuable means to evaluate the magnitude and extent of geochemical effects via fluid-rock interaction during subduction cycling.

The nitrogen $(\mathrm{N})$ isotope system has a great potential as geochemical tracer for crustal and volatile recycling due to the large isotopic differences in the various terrestrial reservoirs (Busigny and Bebout 2013; Halama et al. 2014; Johnson and Goldblatt 2015; Bebout et al. 2016; Mikhail and Howell 2016). Nitrogen is a sensitive tracer for fluid-rock interaction and metasomatic processes (Bebout 1997; Halama et al. 2010; Li et al. 2014), in particular for sediment-derived fluids because $\mathrm{N}$ is largely fixed by organic processes in sedimentary environments (Bebout 1997; Bebout et al. 2016). However, direct evidence of spatially constrained transport of $\mathrm{N}$ is rare, and the processes that cause $\mathrm{N}$ mobilization and fractionation of $\mathrm{N}$ isotopes need to be better understood. It has been established for some metasedimentary suites that $\mathrm{N}$ contents decrease and $\delta^{15} \mathrm{~N}$ values increase with increasing metamorphic grade during subduction (Bebout and Fogel 1992; Mingram and Bräuer 2001). However, other suites show relatively little change and $N$ appears to be retained to depths approaching those beneath arcs (Busigny et al. 2003; Pitcairn et al. 2005). Similarly, metamorphosed mafic and ultramafic rocks appear to largely retain $\mathrm{N}$ to depths of at least $60-70 \mathrm{~km}$ (Halama et al. 2010, 2012; Busigny et al. 2011).

\section{(1)} In this study, we use spatially constrained profiles of metamorphosed mafic igneous rocks that represent the frozen-in advance of fluid-induced metamorphic/metasomatic processes to investigate the behaviour of $\mathrm{N}$ and $\mathrm{N}$ isotopes during prograde and retrograde metamorphic changes. Three profiles were selected that represent i) a prograde transformation of blueschist into eclogite due to fluid ingress from a major fluid conduit (Beinlich et al. 2010; John et al. 2012), ii) a retrograde transformation of eclogite into blueschist during exhumation within a subduction channel (van der Straaten et al. 2012), and iii) an exhumation-related interaction of an eclogite body with surrounding felsic gneisses in a collisional context. The first two sample sequences come from the 
south-eastern Tianshan (China) high-pressure low-temperature (HP-LT) belt, whereas the third profile is from the Variscan Belt in the Vendée (France). We find that prograde dehydration can release large amounts of $\mathrm{N}$ due to the breakdown of white mica, in which $\mathrm{N}$ is incorporated as ammonium $\left(\mathrm{NH}_{4}{ }^{+}\right)$, whereas the associated isotopic changes are relatively small $(<1 \%)$. Hence, non-altered eclogites should largely reflect the $\mathrm{N}$ isotopic composition of their protoliths. In contrast, interaction with retrograde fluids can impart the $\mathrm{N}$ elemental and isotopic characteristics of the rocks with which the fluid equilibrated and hence cause significant perturbations of the $\mathrm{N}$ systematics.

\section{Geologic setting and sample description}

\subsection{Tianshan orogen, (ultra)high-pressure low-temperature ((U)HP-LT) metamorphic belt,} China

Two profiles were sampled in a (U)HP-LT belt of metamorphic rocks in the Chinese part of the Tianshan orogen (Figure 1a). The Tianshan orogen extends morphologically over $2500 \mathrm{~km}$ from north-western China in the east over Kyrgyzstan and Kazakhstan to Tajikistan and Uzbekistan in the west along the southwestern margin of the Central Asian Orogenic Belt, also known as the Altaid Tectonic Collage (e.g., Şengör et al. 1993). In China, the western Tianshan, which includes the (U)HP metamorphic terrane, is situated between the Junggar plate in the north and the Tarim plate in the south (Gao et al. 2009 and references therein). The HP-LT rocks are interpreted as relics of the Palaeozoic South Tianshan Ocean basin and whole rock geochemical data of the mafic rocks show oceanic basalt affinities including former seamounts and young arcs, subducted during Silurian and Carboniferous time (Windley et al. 1990; Şengör and Natal'in 1996; Gao et al. 1998; Gao and Klemd 2003; John et al. 2008). The (U)HP-LT metamorphic terrane comprises predominantly metasediments, which form the host rocks of mafic metavolcanic rocks, metavolcaniclastics, marbles, and ultramafic rocks, and is considered to represent a tectonic mélange formed within an accretionary wedge-like setting on the southern margin of the Central Tianshan Arc terrane during the subduction of the South Tianshan Ocean (e.g., Gao et al. 1999; van der Straaten et al. 2008; Klemd et al. 2011). The mafic metavolcanic rocks (mainly eclogites locally interlayered with blueschists) occur irregularly distributed as differently sized pods, boudins, thin layers or large massive blocks embedded in voluminous metasedimentary host rocks or less abundant surrounded by metavolcaniclastic rocks (Gao and Klemd 2003). Blueschist occurrences 
include prograde and retrograde varieties (Gao and Klemd 2001; Gao et al. 2007; van der Straaten et al. 2008, 2012; Beinlich et al. 2010). Peak-metamorphic conditions of most eclogites and prograde blueschists are similar (both lithologies occur locally with gradual transitions or intimately intercalated) and range between 480 and $580{ }^{\circ} \mathrm{C}$ at $1.4-2.3 \mathrm{GPa}$ at a regional scale (e.g., Klemd et al. 2002; John et al. 2008). Moreover, relics of UHP conditions (e.g. coesite inclusions in garnet) or thermodynamic modelling suggesting UHP conditions for both metasediments and eclogites have been reported with peak $\mathrm{P}-\mathrm{T}$ conditions of $570-630{ }^{\circ} \mathrm{C}$ at $2.7-3.3 \mathrm{GPa}$ for eclogite-facies mica schists and $470-510^{\circ} \mathrm{C}$ at 2.4-2.7 GPa for eclogites from several localities (Lü et al. 2008, 2009; Wei et al. 2009; Tian and Wei 2013). The juxtaposition of UHP and HP eclogite-facies rocks juxtaposed on a meter scale is thought to reflect mixing of eclogite-facies rock from different depths at the plate interface in a subduction channel-like setting (van der Straaten et al. 2008; Lü et al. 2009; Klemd et al. 2011). The timing of peak metamorphic conditions was determined by garnet growth ages of ca. $315 \mathrm{Ma}$ based on multi-point Lu-Hf isochron ages for both blueschists and eclogites from various locations within the (U)HP-LT belt (Klemd et al. 2011). High-pressure veins crosscutting a blueschist wall-rock formed contemporaneously at $317 \pm 5 \mathrm{Ma}(\mathrm{Rb}-\mathrm{Sr})$ which is consistent with metamorphic fluid release due to prograde transformations of blueschists to eclogites (John et al. 2012). U-Pb SIMS ages of metamorphic zircon rims in eclogites are indistinguishable within error at $319 \pm 3 \mathrm{Ma}$ ( $\mathrm{Su}$ et al. 2010). The post-peak cooling was dated by white mica geochronology (K-Ar, Ar-Ar, Rb-Sr) and gave ages between 310 and $311 \mathrm{Ma}$ (Klemd et al. 2005).

For the profiles, drill cores with a diameter of $2.54 \mathrm{~cm}$ and a length of about $10-15 \mathrm{~cm}$ were taken to obtain a good spatial resolution. At both sample localities, the samples occur as loose, meter-sized blocks, which have fallen from the steep mountain slopes as rock falls. The blocks represent a mixture of various rock types that are now found within and partly covered by quaternary deposits.

Profile 1 (JTS sequence; Figure 2a) represents the prograde transformation of blueschist into eclogite due to fluid infiltration. The JTS sequence was studied in detail by Beinlich et al. (2010) and John et al. (2012), and the following summary is based on these works. The massive blueschist with the main mineral assemblage garnet + glaucophane + omphacite + phengite + quartz is crosscut by a carbonate-quartz vein, which is surrounded by an eclogitic reaction halo mainly composed of omphacite and garnet. The vein represents a major former fluid pathway that shows fluid infiltration from an external source and dehydration of the immediate wall rock. Important petrographic observations of the fluid-induced eclogitization include replacement of sodic amphibole by omphacitic clinopyroxene, increase in the modal abundances of quartz and carbonate 
and decrease in the modal abundance of white mica with decreasing distance to the vein. The successive breakdown of white mica towards the vein is responsible for a relative depletion in large-ion lithophile elements (LILE: $\mathrm{K}, \mathrm{Rb}$, and $\mathrm{Cs}$ ) in the eclogitic selvage compared to the host blueschist. Enrichments in $\mathrm{Ca}, \mathrm{Pb}$ and $\mathrm{Sr}$ and depletions in HFSE can also be attributed to the fluidinduced eclogitization.

Profile 2 (FTS 9-1 sequence; Figure 2b) represents a gradual retrograde transition from eclogite to blueschist caused by fluid-rock interaction during uplift in the subduction channel (van der Straaten et al. 2008, 2012). The following description is based on the petrologic-geochemical investigation by van der Straaten et al. (2012) on these samples. The eclogitic parts consist of a fine-grained omphacite matrix with accessory rutile and porphyroblasts of garnet. The fluid-induced blueschist-facies overprint caused replacement of the eclogite-facies assemblage by newly formed glaucophane, paragonite, chlorite, calcite and titanite. The increase in the modal amounts of glaucophane, white mica and calcite with increasing blueschist-facies overprint lead to a nearly complete replacement of omphacite in the glaucophane schist.

\subsection{Les Essarts Unit, Variscan Belt, Vendée, France}

Samples were taken along a $\sim 100 \mathrm{~m}$ long profile from an approximately $1 \mathrm{~km}$ thick eclogite lens via retrogressed eclogite and amphibolite into surrounding metasedimentary gneiss in the quarry "La Gerbaudière" of the Les Essarts Unit, $25 \mathrm{~km}$ south of Nantes and west of St. Philbert de Bouaine (Figure 1b). This unit constitutes a HP metamorphic basement complex of the Southern Armorican Massif that is part of the Variscan belt (Matte 2001). Rocks of oceanic origin (eclogites, amphibolites derived from eclogite, meta-plagiogranites and serpentinites) form several km-long stretched and slightly boudinaged lenses surrounded by foliated ortho- and paragneisses that are rich in white mica (Mauler et al. 2001). The eclogites have gabbroic protoliths with a crystallization age of $1297 \pm 60 \mathrm{Ma}$ based on a zircon U-Pb upper intercept age (Peucat et al. 1982). The eclogitefacies metamorphism was dated at $436 \pm 15 \mathrm{Ma}$ based on a zircon U-Pb lower intercept age (Peucat et al. 1982). The primary HP mineral assemblage is omphacite + garnet + rutile \pm quartz \pm kyanite \pm zoisite \pm magnesio-hornblende \pm pyrite \pm chalcopyrite and peak P-T conditions are 1.6-2.0 GPa and $650-750{ }^{\circ} \mathrm{C}$ (Godard 2009). A major deformation event occurred during the eclogite-facies metamorphism, followed by retrogression that transformed most of the eclogites into amphibolites, in particular affecting the margins of the eclogite lenses. Retrogression is indicated by presence of green amphibole and plagioclase-clinopyroxene symplectite along omphacite grain boundaries 
197 (Mauler et al. 2001). The gneisses surrounding the eclogites with the main mineral assemblage 198 quartz + plagioclase + biotite + garnet + white mica are of continental origin and record two distinct 199 episodes of high-grade metamorphism (Godard 2009). The first event comprises intrusion of granite 200 and migmatisation of cordierite-bearing metapelites $\left(\mathrm{T} \sim 670^{\circ} \mathrm{C}, \mathrm{P}=0.3 \mathrm{GPa}\right)$ within the pre201 Variscan continental crust. The second event is an eclogite-facies overprint, cofacial with the 202 eclogitization of the adjacent oceanic mafic rocks at peak P-T conditions of P $>1.6$ GPa and $\mathrm{T} \sim$ $203700^{\circ} \mathrm{C}$, which occurred during eo-Variscan subduction (Bernard-Griffiths and Cornichet 1985; 204 Godard 2009) with simultaneous deformation of eclogites and gneisses. Several coronitic and 205 pseudomorphic reactions caused the growth of high-pressure minerals (garnet, kyanite, phengite, 206 rutile) and the expense of the previous high-temperature parageneses (Godard 2009). The Les 207 Essarts Unit is interpreted as tectonic mélange of pre-Variscan oceanic and continental crusts that 208 were eclogitized during subduction and subsequently incorporated into the Variscan orogenic belt 209 (Godard 2001).

212 [Figure 1 near here]

213 [Figure 2 near here]

\section{Analytical methods}

\subsection{Nitrogen content and nitrogen isotopic compositions}

Nitrogen concentrations and isotopic compositions of bulk rock powders were analysed at Lehigh University. Sample preparation and analytical protocol follow the methods described in Bebout et al. (2007). In brief, about $100-250 \mathrm{mg}$ of sample powder and $\mathrm{Cu} / \mathrm{CuOx}$ reagent are evacuated for $24 \mathrm{~h}$ before sealing, with intermittent heating to $\sim 100{ }^{\circ} \mathrm{C}$. Nitrogen is extracted at $1000{ }^{\circ} \mathrm{C}$ and transferred as $\mathrm{N}_{2}$ into a Finnigan MAT 252 mass spectrometer using a Finnigan Gas Bench II and a U-trap interface in which samples of $\mathrm{N}_{2}$ are entrained in a He stream. Details regarding the calculation of $\mathrm{N}$ concentrations in unknowns and reference materials analysed during the course of this study can be found in Halama et al. $(2010,2014)$. The analytical uncertainties for $\mathrm{N}$ concentrations are usually $<5 \%$. For $\delta^{15} \mathrm{~N}$ values (referenced to the isotopic composition of 
atmospheric $\mathrm{N}_{2}$, “air"), uncertainties are $0.15 \%$ o $(1 \sigma)$ for samples with $>5 \mu \mathrm{g} / \mathrm{g} \mathrm{N}$ and $0.6 \%$ ( $\left.1 \sigma\right)$ for samples with $1-5 \mu \mathrm{g} / \mathrm{g} \mathrm{N}$.

\subsection{Major and trace elements}

Major and trace element data of the JTS and FTS traverses were published in Beinlich et al. (2010) and van der Straaten et al. (2012), respectively, and are reproduced in the supplemental dataset. Major and trace elements of the Vendée traverse (supplemental dataset) were analysed by X-ray fluorescence at Universität Heidelberg using a Siemens ${ }^{\circledR}$ SRS303 instrument equipped with a Rhtube. Major and minor elements were measured on fused glass discs with an accuracy of $0.5-1 \%$. Trace elements $(\mathrm{Cr}, \mathrm{Ni}, \mathrm{Sr}, \mathrm{Zr}, \mathrm{Ba})$ were measured on pressed pellets with an accuracy of 5-10\%. Further details about the XRF methods are given in Pauly et al. (2016). Lithium concentrations were determined at the University of Bristol with a sample-standard bracketing technique using a ThermoElectron ${ }^{\circledR}$ Neptune MC-ICP-MS as described in Marschall et al. (2007b). Concentrations were determined by intensity comparison with the bracketing standard (NIST L-SVEC) and have a precision of approximately $\pm 10 \%$.

\section{Results}

In the profile representing the prograde blueschist-eclogite transformation (JTS sequence), N concentrations successively decrease from the host blueschist $(\sim 26 \mu \mathrm{g} / \mathrm{g})$ to the blueschist-eclogite transition zone (BETZ; 19-23 $\mu \mathrm{g} / \mathrm{g}$ ) and the eclogitic selvage (12-16 $\mu \mathrm{g} / \mathrm{g}$; Figure 3a). The quartzcarbonate vein has the lowest $\mathrm{N}$ concentrations $(9.5 \mu \mathrm{g} / \mathrm{g})$ and the highest $\delta^{15} \mathrm{~N}_{\text {air }}$ value $(+4.8 \%$ o in this sequence (Table 1). Nitrogen isotopic compositions of the eclogitic selvage $\left(\delta^{15} \mathrm{~N}=+2.6 \pm\right.$ $0.2 \%$ ) are slightly elevated compared to the BETZ $(+2.0 \pm 0.2 \%)$ and the host blueschists $\left(\delta^{15} \mathrm{~N}=\right.$ +1.8 to $+2.3 \%$ ). Overall, the profile shows a systematic decrease in [N] from the host wall rock towards the vein, which is paralleled by LILE such as Rb (Figure 3a; supplemental dataset). Excluding the vein, the overall range in $\delta^{15} \mathrm{~N}$ in eclogites and blueschists is very limited (only about $1 \%$ ) with an average of $+2.1 \pm 0.3 \%$ ( $n=9)$.

In the profile representing the retrograde eclogite-blueschist transition (FTS sequence), there is a broad increase in $\mathrm{N}$ contents from the eclogite towards the blueschist, but the trend shows significant scatter and there is also variability between adjacent samples from the same drill core (3.1-3A and 3.1-3B). The overall range in $\mathrm{N}$ contents $(8-27 \mu \mathrm{g} / \mathrm{g})$ is comparable to the JTS 
sequence, but the variability in $\delta^{15} \mathrm{~N}$ is larger $\left(\delta^{15} \mathrm{~N}=+1.0\right.$ to $+5.4 \%$ ). $\delta^{15} \mathrm{~N}$ varies unsystematically with regard to distance along the profile (Table 1).

In the eclogite-gneiss profile, the country rock gneisses have high $\mathrm{N}$ contents $(14-52 \mu \mathrm{g} / \mathrm{g})$ and positive $\delta^{15} \mathrm{~N}$ values $(+2.9$ to $+5.8 \%$; Table 1$)$. $\delta^{15} \mathrm{~N}$ values of both garnet amphibolites and eclogites are within the range of the gneiss values, but $[\mathrm{N}]$ becomes increasingly lower towards the eclogite with 11-24 $\mu \mathrm{g} / \mathrm{g}$ for the amphibolites and $10-14 \mu \mathrm{g} / \mathrm{g}$ for the retrogressed eclogite (Figure $3 \mathrm{~b})$. The pristine eclogite is characterized by the lowest $\mathrm{N}$ concentrations $(2.1-3.6 \mu \mathrm{g} / \mathrm{g})$ and the lightest $\mathrm{N}$ isotopic compositions $\left({ }^{15} \mathrm{~N}=+2.1\right.$ to $+3.6 \%$ ). The elements $\mathrm{Ba}$ and Li show a similar behaviour as $\mathrm{N}$ with successively decreasing concentrations from the gneisses to the eclogites (Figure 3b; supplemental dataset).

[Figure 3 near here]

[Table 1 near here]

\section{Discussion}

\subsection{Residency of nitrogen}

Nitrogen occurs as ammonium $\left(\mathrm{NH}_{4}{ }^{+}\right)$in most silicate minerals, where it substitutes for $\mathrm{K}^{+}$due to the similarity of these ions in charge and ionic radius. $\mathrm{NH}_{4}{ }^{+}$is thus most strongly concentrated in micas and alkali feldspars in many crustal rocks (Honma and Itihara 1981), as reflected by correlations of $\mathrm{N}$ contents with concentrations of LILE (K, Rb, Cs, Ba) in several metasedimentary suites (Bebout et al. 1999; Busigny et al. 2003; Sievers et al. 2016, this issue). Phengite (Si-rich potassic white mica) is the main $\mathrm{N}$ carrier mineral in high- $P / T$ metamorphosed mafic and ultramafic rocks, but $\mathrm{NH}_{4}^{+}$may also occur in Ca-Na minerals where phengite is absent (Busingy et al., 2011; Halama et al., 2010; 2012). The positive correlation of $\mathrm{N}$ with K, Ba, Rb and Cs (Figure 4) in both Tianshan sequences points to a mineralogical control by phengite regarding the $\mathrm{N}$ concentrations in the bulk rocks, because phengite is known to be the principal carrier for these elements in phengitebearing eclogites and high- $P / T$ metapelites (e.g., Sorensen et al. 1997; Zack et al. 2001).

The JTS sequence shows the most striking correlation among $\mathrm{N}$ abundances and LILE concentrations, with a systematic decrease from host blueschists via the BETZ towards eclogites and the vein (Figure $4 \mathrm{a}$ ). The key role of phengite as $\mathrm{N}$ host is underlined by the decreasing modal 
occurrence of white mica (phengite + paragonite) towards the vein (Figure 5; Beinlich et al. 2010).

298 The somewhat larger scatter in the FTS sequence (Figure 4b) may be related to the generally much smaller concentration variations compared to the JTS sequence. Moreover, paragonite (sodic white mica) forms in response to the retrograde overprint in the FTS sequence. Although paragonite is capable of incorporating significant amounts of $\mathrm{N}$ in the order of up to $100 \mu \mathrm{g} / \mathrm{g}$ (Busigny et al. 2011), phengite frequently contains several hundreds of $\mu \mathrm{g} / \mathrm{g}$ (Sadofsky and Bebout 2000) and is hence a more likely major $\mathrm{N}$ host. The unsystematic variations in modal abundances of these two phases are therefore thought to contribute to the scattered trends in the FTS sequence. In the eclogite-gneiss profile, there is a systematic, coupled increase in N and LILE as well as Li from eclogites via retrogressed eclogites and amphibolites towards the surrounding gneisses (Figure 4c). The low $\mathrm{N}$ contents in the eclogites are consistent with the lack of K-bearing phases. Any N present is probably residing in omphacitic $(\mathrm{Na}-\mathrm{Ca})$ clinopyroxene, in agreement with observations from natural metagabbros (Busigny et al. 2011) and experimental results that show the potential of clinopyroxene to incorporate $\mathrm{N}$ at ultrahigh pressures (Watenphul et al. 2010). Additional $\mathrm{N}$ present in retrogressed eclogites and amphibolites may be incorporated into plagioclase, for which $\mathrm{N}$ concentrations of $2-45 \mu \mathrm{g} / \mathrm{g}$ have been reported, substituting for $\mathrm{Ca}$ and $\mathrm{Na}$ (Honma and Itihara 1981), and to a lesser degree into amphibole (2-5 $\mu \mathrm{g} / \mathrm{g} \mathrm{N}$, Honma and Itihara 1981). In the gneisses, $\mathrm{N}$ can be incorporated into muscovite and biotite, both of which can host large amounts $(>1000$

[Figure 4 near here]

[Figure 5 near here]

\subsection{Nitrogen elemental and isotopic characteristics}

All three of the sample suites are characterized by a limited $(\leq 5 \%)$ variation in $\delta^{15} \mathrm{~N}$ and positive $\delta^{15} \mathrm{~N}$ values, which distinguishes them from fresh MORB (Figure 6). Most of the $\delta^{15} \mathrm{~N}$ values of the mafic samples overlap with those of global eclogites, which were interpreted to largely reflect the $\mathrm{N}$ isotope compositions of their protolith (altered oceanic crust, $\mathrm{AOC}$ ) with or without the effects of metamorphic dehydration (Halama et al. 2010). Metamorphic dehydration generally causes a decrease in $\mathrm{N}$ concentrations and an increase in $\delta^{15} \mathrm{~N}$ values (Haendel et al. 1986; Bebout and Fogel 1992), but the large compositional variability of AOC hinders the identification 
331 of dehydration effects. At each location, some of the mafic samples have elevated $\mathrm{N}$ contents relative to global eclogites, in particular the Tianshan blueschists and the Vendée amphibolites, trending towards compositions of metasediments (Figure 6). In the prograde blueschist-eclogite JTS sequence, the blueschists represent the rocks least affected by eclogitization-causing fluid overprint, and hence may have inherited their signature during a previous metasomatic event, e.g. during seafloor alteration or blueschist-facies metamorphism. The trend in the JTS sequence towards relatively $\mathrm{N}$-poor compositions is unlikely to be entirely due to a decreasing modal abundance of white mica as suitable host mineral for $\mathrm{N}$ because the modal abundances of white mica are similar in the host blueschists (8-11\%) and the BETZ (12-15\%), with only the eclogitic selvage having lower contents (4-11\%; Beinlich et al. 2010). Hence, the trend suggests that the fluid inducing the eclogitization was relatively poor in $\mathrm{N}$ and probably not of sedimentary origin. This finding is in agreement with the $\mathrm{Ca}$ and $\mathrm{Sr}$ isotope data pointing to a dehydrating oceanic lithosphere, i.e. AOC or serpentinized slab mantle, as potential fluid source (John et al., 2012). An estimate for the average $\delta^{15} \mathrm{~N}$ of ultramafic rocks recycled into the mantle is $+3 \pm 2 \%$ (Halama et al. 2014), but individual serpentinized peridotite samples have even more positive $\delta^{15} \mathrm{~N}$ values of up to $+15 \%$ (Philippot et al. 2007).

In contrast, the blueschists of the FTS sequence are among the samples that are most strongly affected by retrograde metasomatism. Their elevated $\mathrm{N}$ contents at moderately positive $\delta^{15} \mathrm{~N}$ are consistent with a metasomatic overprint by a fluid that either originated from or equilibrated with metasedimentary rocks. In the Vendée profile, the field evidence clearly demonstrates increasing fluid-induced overprint of the eclogite lens by fluids derived from the surrounding metasedimentary gneisses, producing the sequence fresh eclogite - retrogressed eclogite - amphibolite metasedimentary gneiss. This profile allows evaluation of the effects of the metasedimentary fluids on $[\mathrm{N}]$ and $\delta^{15} \mathrm{~N}$ in the eclogite lens. Both the $\mathrm{N}$ concentrations and the $\delta^{15} \mathrm{~N}$ values increase in the metasomatically overprinted mafic rocks compared to the pristine eclogite. These features can be explained by assuming that the country rock paragneisses with high $\mathrm{N}$ contents and an adequate $\mathrm{N}$ isotopic composition were the source lithology for the metasomatic fluids, corroborating the field evidence. Hence, both the Tianshan FTS and the Vendée profile underline the sensitivity of the N system to sediment-derived fluids. These fluids incorporated biogenic $\mathrm{N}$ that was originally present as organic matter in the sediments. Granitic rocks from the Cornubian batholith similarly show high $\mathrm{N}$ contents $(6-139 \mu \mathrm{g} / \mathrm{g})$ and positive $\delta^{15} \mathrm{~N}(+5$ to $+10 \%$ ) values (Boyd et al. 1993). These features were interpreted to reflect inheritance of $\mathrm{N}$ of biological origin as the granites are essentially derived from the anatexis of $\mathrm{NH}_{4}{ }^{+}$-bearing metasediments that originally contained organic material (Hall 1987; Boyd et al. 1993). 
[Figure 6 near here]

\subsection{Fluid-rock interaction processes}

In this section, we focus on the prograde blueschist-eclogite JTS sequence because it shows a relatively simple mineralogical control on $\mathrm{N}$ contents, resulting in clear correlations that can be compared to various fluid-rock interaction processes potentially affecting the rocks. Busigny and Bebout (2013) summarized four types of $\mathrm{N}$ exchange between mineral and fluid that can be distinguished during metamorphism, and each of these will be evaluated in turn:

(1) Thermal decomposition: Thermal decomposition causes the complete breakdown of mineral hosts due to increasing temperatures and the onset of partial melting. This leads to a decreasing modal abundance of mica and loss of $\mathrm{N}$ if no other suitable host phases for $\mathrm{N}$, such as $\mathrm{K}$-feldspar (incorporation of $\mathrm{NH}_{4}^{+}$) or cordierite (incorporation of $\mathrm{N}_{2}$ in channels of the mineral structure), are present in the melting residue (Palya et al. 2011). Thermal decomposition can be excluded in the studied profiles because there is no field or petrographic evidence for partial melting and estimates of peak temperatures are too low for partial melting of mafic rocks to occur.

(2) Cation exchange: Cation exchange of $\mathrm{NH}_{4}{ }^{+}$and $\mathrm{K}^{+}$between white mica and a fluid can release mica by $\mathrm{K}^{+}$(Eugster and Munoz 1966; Busigny and Bebout 2013). A similar exchange may occur between $\mathrm{NH}_{4}^{+}$and $\mathrm{Rb}^{+}$or $\mathrm{Cs}^{+}$. This process is expected to cause a negative correlation of $\mathrm{NH}_{4}^{+}$ with $\mathrm{K}^{+}$(and $\mathrm{Rb}^{+}, \mathrm{Cs}^{+}$). However, all investigated profiles show a positive correlation of $\mathrm{K}$ and $\mathrm{N}$. This is the opposite behaviour to what would be expected if cation exchange was the dominant

(3) Continuous metamorphic devolatilization reactions: Devolatilization reactions during prograde metamorphism cause changes in mica chemistry and mica modal abundances in the rock (Bebout and Fogel 1992; Bebout et al. 2013). During devolatilization, isotopically light $\mathrm{N}$ is preferentially fractionated into the metamorphic fluid. Consequently, residual mica records an increase in $\delta^{15} \mathrm{~N}$ with increasing degrees of devolatilization (Haendel et al. 1986; Bebout and Fogel 1992; Jia et al. 
2006). To test the effects of metamorphic devolatilization, we calculated the composition of the residual rock for batch devolatilization and Rayleigh distillation models (Figure 7a). In an opensystem Rayleigh distillation model, each fluid increment produced by phengite dehydration is immediately removed from the rock. In contrast, the batch devolatilization model assumes that all of the fluid released equilibrates with the rock and is lost in a single batch (Valley 1986).

The isotopic fractionation depends on the $\mathrm{N}$ speciation in the fluid $\left(\mathrm{N}_{2}\right.$ or $\left.\mathrm{NH}_{3}\right)$. It is evident that devolatilization models involving $\mathrm{NH}_{3}$ cannot explain the observed trend in the JTS sequence (Figure 7a). Busigny et al. (2003) modelled phengite chemical evolution during progressive Rayleigh distillation for LILE, and we use this approach to test the applicability of continuous metamorphic reactions on the prograde blueschist-eclogite JTS data set (Figure 7b, c). Different partition coefficients between fluid and phengite for $\mathrm{K}, \mathrm{Rb}, \mathrm{Cs}$ and $\mathrm{N}$ cause fractionation between these elements during devolatilization (Melzer and Wunder 2000; Busigny et al. 2003). Since all these elements predominantly resided in phengite, their ratios in phengite reflect those of the whole rock (Zack et al. 2001). Caesium has a larger preference for the fluid than both $\mathrm{Rb}$ and $\mathrm{N}$, producing a relatively sharp decrease in Cs abundances and curved Rayleigh distillation trends in bivariate diagrams (Figure $7 \mathrm{~b}, \mathrm{c}$ ). The linear correlations of the measured data suggest that continuous metamorphic phengite dehydration via a Rayleigh distillation process in an open system cannot have caused the coupled decrease in Rb-Cs and N-Cs, respectively. The coupled losses of these elements which are observed with decreasing distance to the vein do not appear to obey a $\mathrm{K}_{\mathrm{d}^{-}}$ controlled Rayleigh distillation process. However, a good fit to the JTS data is obtained for a $\mathrm{N}_{2}$ batch devolatilization model, only the vein plots off the modelled trend (Figure 7a). Hence, the N isotope data support a batch devolatilization process.

\section{[Figure 7 near here]}

(4) Fluid-induced breakdown of white mica: It has been shown that the eclogitization adjacent to the vein structure occurred due to fluid-mediated replacement processes during which the blueschist continuously equilibrated with an external fluid characterized by a composition that differed strongly from that of the wall rock blueschist (Beinlich et al. 2010; John et al. 2012). Consequently, the blueschist mineral assemblage has been successively replaced by a new eclogite assemblage (Putnis and Austrheim 2010; Putnis and John 2010). This process can be generalised by breakdown reactions such as: 


$$
2 \mathrm{KAl}_{2}\left(\mathrm{Si}_{3} \mathrm{AlO}_{10}\right)(\mathrm{OH})_{2}+2 \mathrm{H}^{+}=3 \mathrm{Al}_{2} \mathrm{SiO}_{5}+3 \mathrm{SiO}_{2}+2 \mathrm{~K}^{+}+3 \mathrm{H}_{2} \mathrm{O}
$$

$$
2 \mathrm{KAl}_{2}\left(\mathrm{Si}_{3} \mathrm{AlO}_{10}\right)(\mathrm{OH})_{2}=3 \mathrm{Al}_{2} \mathrm{SiO}_{5}+3 \mathrm{SiO}_{2}+2 \mathrm{~K}^{+}+2 \mathrm{OH}^{-}+\mathrm{H}_{2} \mathrm{O}
$$

Once liberated from phengite, $\mathrm{N}$ and the LILE (formerly substituting for $\mathrm{K}$ in phengite) enter the fluid, which mediates diffusive or advective transport towards the nearest transport vein leading to long-distance element removal (Zack and John 2007). This process of fluid-induced decomposition of white mica is in agreement with the coupled bulk losses of LILE and N. The combined stripping of LILE and $\mathrm{N}$ from the blueschists requires infiltration of a K-poor fluid, which drives chemical reactions towards reduced chemical potential gradients for fluid species by destroying phengite and releasing LILE and $\mathrm{N}$ into the fluids (Breeding et al. 2004; John et al. 2012). Loss of $\mathrm{Al}_{2} \mathrm{O}_{3}$ in both the BETZ ( 2-9\%) and in the eclogitic selvage ( $\sim 12 \%)$ compared to the blueschist host (Beinlich et al. 2010) suggest release and removal of $\mathrm{Al}$ during phengite breakdown. The behaviour of Si is less systematic, with some relative losses in BETZ samples but also gains in the eclogitic selvage (Beinlich et al. 2010), likely related to infiltration from the vein-forming fluid.

If the fluids infiltrating the rock are highly oxidising, $\mathrm{NH}_{4}{ }^{+}$will be partially oxidised to $\mathrm{N}_{2}$, which will then be lost from the system in the fluid (Bebout and Fogel 1992; Svensen et al. 2008). Oxidizing fluids are capable of destroying ammonium muscovite and forming kyanite and quartz by the reaction (Eugster and Munoz 1966):

$$
2 \mathrm{NH}_{4} \mathrm{Al}_{2}\left(\mathrm{Si}_{3} \mathrm{AlO}_{10}\right)(\mathrm{OH})_{2}+1.5 \mathrm{O}_{2}=3 \mathrm{Al}_{2} \mathrm{SiO}_{5}+3 \mathrm{SiO}_{2}+\mathrm{N}_{2}+6 \mathrm{H}_{2} \mathrm{O}
$$

More reducing fluids may cause breakdown of ammonium muscovite by the reaction

$$
2 \mathrm{NH}_{4} \mathrm{Al}_{2}\left(\mathrm{Si}_{3} \mathrm{AlO}_{10}\right)(\mathrm{OH})_{2}=3 \mathrm{Al}_{2} \mathrm{SiO}_{5}+3 \mathrm{SiO}_{2}+2 \mathrm{NH}_{3}+3 \mathrm{H}_{2} \mathrm{O}
$$

453 Generally, fluid-rock interaction can be considered as an important mechanism to release large amounts of specific elements that are hosted by a single mineral phase. Regarding the transport of LILE and N, phengite mode and breakdown rate are the most important parameters of the rock for storage and release, respectively, of these elements. The combined $\mathrm{N}$ elemental and isotope systematics suggest a scenario of fluid-induced breakdown of white mica and batch devolatilization of $\mathrm{N}$ in the system.

\subsection{Transfer and sources of nitrogen}

The prograde blueschist-eclogite transition of the JTS sequence, which is induced by metasomatism, provides compelling evidence for removal of $\mathrm{N}$ due to phengite breakdown. Other elements, such as $\mathrm{Ca}, \mathrm{Sr}$ and $\mathrm{Pb}$, were added by the fluid-induced overprint (Beinlich et al. 2010), and consequently exhibit negative correlations with $\mathrm{N}$ contents (Figure 8). The degree to which $\mathrm{N}$ 
potentially present in the fluid would have been able to exchange with the rock and alter [N] and $468 \delta^{15} \mathrm{~N}$ depends on the compatibility of $\mathrm{N}$ in the available mineral hosts and the abundance of these 469 host phases. In the metasomatically formed eclogites of the JTS sequence, no other mineral except 470 phengite is able to incorporate significant amounts of $\mathrm{N}$. The $\delta^{15} \mathrm{~N}_{\text {fluid }}$ is estimated as $\sim+7 \%$ based 471 on vein composition and the $\mathrm{NH}_{4}{ }^{+}-\mathrm{N}_{2}$ fractionation factor at $527^{\circ} \mathrm{C}$ from Hanschmann (1981). 472 Positive $\delta^{15} \mathrm{~N}$ that overlap the vein composition were observed in AOC from the East Pacific Rise 473 (Busigny et al. 2005) and in various (meta)sedimentary rocks (Figure 9a). However, the 474 combination of a high- $\delta^{15} \mathrm{~N}$ fluid that introduced large amounts of externally-derived $\mathrm{Ca}$ and $\mathrm{Sr}$, but 475 not LILE, is pointing towards AOC rather than (meta)sediments as the most likely fluid source. 476 This conclusion is consistent with $\mathrm{Ca}-\mathrm{Sr}$ isotope data, which demonstrated that seawater-altered 477 lithospheric rocks were the dominant source for the metasomatic fluid that induced eclogitization in 478 the JTS sequence (John et al. 2012). In the $\delta^{15} \mathrm{~N}-\mathrm{Rb} / \mathrm{N}$ diagram (Figure 9a), where mixing 479 relationships appear as straight lines, an apparent mixing trend between the JTS rock with the 480 highest $\mathrm{Rb} / \mathrm{N}$ ratio and the vein composition yields a decent fit to the data points. Our preferred 481 interpretation of this apparent mixing relationship is that up to $\sim 40 \%$ of the initially present 482 phengite was destroyed by the fluid-induced overprint, in agreement with the observed decrease of 483 modal phengite abundance (Beinlich et al. 2010), causing successively decreasing $\mathrm{Rb} / \mathrm{N}$ ratios 484 coupled to decreasing $\mathrm{N}$ contents. Changes in $\delta^{15} \mathrm{~N}$ in the overprinted eclogites compared to the 485 blueschists are minor and an externally-derived $\mathrm{N}$ isotope signature is not clearly discernible from $\delta^{15} \mathrm{~N}$ variability due to protolith heterogeneities \pm devolatilization effects.

In contrast to the JTS sequence, both of the two profiles with a retrograde overprint, the FTS sequence and the Vendée profile, show addition of N during metasomatism. For the FTS sequence, the addition was not pervasive and systematic, as the [N]-distance relationships are scattered, possibly related to the availability of fluid pathways within the rock and/or small-scale heterogeneities. The straight line correlation on the $\delta^{15} \mathrm{~N}-\mathrm{Rb} / \mathrm{N}$ diagram (Figure 9a) points to a mixing relationship, but the position of both eclogite and blueschist at the upper end of this trend add a complexity likely related to the co-existence of phengite and paragonite, which precludes any further conclusions.

Retrograde alteration in the Vendée mafic rocks was accompanied by increasing $\mathrm{K} / \mathrm{N}$ ratios and $\delta^{15} \mathrm{~N}$ values (Figure 9b). Any metasomatic fluid entering the eclogite lenses must have passed through the surrounding paragneisses, which therefore constitute the most likely source for any elements added to the eclogites. Retrogressed eclogites and amphibolites are enriched in $\mathrm{N}$ up to 10 times compared to the precursor eclogites and $\delta^{15} \mathrm{~N}$ has been changed by up to $4 \%$. Original protolith signatures and effects of prograde metamorphism were overprinted by the retrograde 
501 metamorphism as $\mathrm{N}$ has been transported on length scales of at least several 10s of meters, although 502 the most pristine eclogites may still preserve the original signatures. The contribution by the 503 relatively $\mathrm{N}$-rich, high- $\delta^{15} \mathrm{~N}$ paragneisses is exemplified by mixing relationships between two 504 different gneisses and eclogite where the whole-rock $\mathrm{K} / \mathrm{N}$ ratios are considered to approximate 505 those of the fluid (Figure 9b). Given the large spread in $\mathrm{K} / \mathrm{N}$ ratios in the gneisses, fluid-mediated 506 mixing can easily explain elevated $\mathrm{K} / \mathrm{N}$ in retrograde overprinted eclogites. The complete overlap in $507 \delta^{15} \mathrm{~N}$ between retrogressed eclogites/amphibolites and gneisses provides evidence for the great 508 sensitivity of the $\mathrm{N}$ isotope system to fluids that interacted with or are derived from 509 (meta)sediments. Amphibolites and retrogressed eclogites have isotopically almost fully 510 equilibrated with the gneisses, and heterogeneities, inherited from the eclogite precursor, were only 511 preserved in the inner parts of the eclogite lens. The fluid-mediated influx of $\mathrm{N}$ from the gneisses 512 into the eclogite lens was likely aided by transport of $\mathrm{N}$ via amphibole veins, which occur in the 513 eclogites and served as more effective transport pathway compared to the less permeable bulk rock. 514 The Vendée profile not only shows direct evidence for the derivation of $\mathrm{N}$ in a metasomatic fluid 515 from metasedimentary rocks, but, importantly, that this process can happen on length scales of 10s 516 of meters.

519 [Figure 8 near here]

$520 \quad$ [Figure 9 near here]

\section{Conclusions}

We investigated three profiles in metasomatically overprinted high-pressure metamorphic rocks to determine the effects of fluid-rock interaction on $\mathrm{N}$ elemental and isotopic systematics. Positive correlations of $\mathrm{N}$ with $\mathrm{K}, \mathrm{Ba}, \mathrm{Rb}$ and $\mathrm{Cs}$ in blueschists and eclogites demonstrate that phengitic white mica is the major $\mathrm{N}$ host in metamorphic rocks with mafic precursors. During prograde overprint of blueschists and transformation into eclogites, the observed straight line correlations between $\mathrm{N}$ and LILE and near-constant ratios of $\mathrm{N} / \mathrm{K}, \mathrm{N} / \mathrm{Rb}, \mathrm{N} / \mathrm{Cs}$ and $\mathrm{Cs} / \mathrm{Rb}$ do not resemble differential losses related to differing equilibrium partitioning during metamorphic devolatilization via a Rayleigh distillation process, but instead indicate that fluid-mediated $\mathrm{N}$ mobilization and loss from the rock is related to complete breakdown of white mica. Hence, $\mathrm{N}$ abundances are strongly controlled by the stability and presence of white mica in HP metamorphic rocks, and external $\mathrm{N}$ 
535 contributions to the whole rock budget remain insignificant as long as no other $\mathrm{N}$ host forms. Fluid536 induced breakdown of phengite in HP rocks can liberate large amounts of $\mathrm{N}$ that is released into the 537 fluid (Figure 10). The $\mathrm{N}$ isotopic compositions show only small variations that are consistent with a 538 batch devolatilization process coupled to the phengite breakdown. During fluid-induced retrograde 539 overprint of eclogites, the $\mathrm{N}$ system is highly sensitive to fluids that equilibrated with 540 metasedimentary rocks and can be used to trace the extent of $\mathrm{N}$ transport from host rocks into 541 eclogite lenses. This transport can occur over several tens of meters and affect both $\mathrm{N}$ 542 concentrations and isotopic compositions (Figure 10), as evidenced by a profile from 543 metasedimentary gneisses into an eclogite lens. Elevated N contents in retrogressed mafic HP rocks 544 suggest that plagioclase and amphibole are capable to incorporate $\mathrm{N}$ derived from metasomatic 545 fluids.

548 [Figure 10 near here]

\section{Acknowledgements}

552 HRM would like to thank Gaston Godard for field guidance in the Vendée. Lithium concentration 553 data were previously unpublished and were provided by Philip Pogge von Strandmann, which is 554 gratefully acknowledged. We thank Sarah Penniston-Dorland and Vincent Busigny for the 555 constructive reviews that helped to greatly improve the manuscript. Support of this project was 556 partly provided by National Science Foundation grant EAR-0711355 to GEB. 
Bebout, G.E., 1997, Nitrogen isotope tracers of high-temperature fluid-rock interactions: Case study of the Catalina Schist, California: Earth and Planetary Science Letters, v. 151, p. 77-90.

Bebout, G.E., 2007, Metamorphic chemical geodynamics of subduction zones: Earth and Planetary Science Letters, v. 260, p. 373-393.

Bebout, G.E., 2014, Chemical and isotopic cycling in subduction zones, in Rudnick, R. L., ed., Treatise on Geochemistry: The Crust, $2^{\text {nd }}$ ed., Volume 3, Elsevier, p. 703-747.

Bebout, G.E., Agard, P., Kobayashi, K., Moriguti, T., and Nakamura, E., 2013, Devolatilization history and trace element mobility in deeply subducted sedimentary rocks: Evidence from Western Alps HP/UHP suites: Chemical Geology, v. 342, p.1-20.

Bebout, G.E., and Fogel, M.L., 1992, Nitrogen-isotope compositions of metasedimentary rocks in the Catalina Schist, California: Implications for metamorphic devolatilization history: Geochimica et Cosmochimica Acta, v. 56, p. 2839-2849.

Bebout, G.E., Idleman, B.D., Li, L., and Hilkert, A., 2007, Isotope-ratio-monitoring gas chromatography methods for high-precision isotopic analysis of nanomole quantities of silicate nitrogen: Chemical Geology, v. 240, p. 1-10.

Bebout, G.E., Lazzeri, K.E., and Geiger, C.A., 2016, Pathways for nitrogen cycling in Earth's crust and upper mantle: A review and new results for microporous beryl and cordierite: American Mineralogist, v. 101, p. 7-24.

Bebout, G.E., and Penniston-Dorland, S.C., 2016, Fluid and mass transfer at subduction interfaces The field metamorphic record: Lithos, v. 240-243, p. 228-258.

Beinlich, A., Klemd, R., John, T., and Gao, J., 2010, Trace-element mobilization during Cametasomatism along a major fluid conduit: Eclogitization of a blueschist as a consequence of fluid-rock interaction: Geochimica et Cosmochimica Acta, v. 74, p. 1892-1922.

Bernard-Griffiths, J., and Cornichet, J., 1985, Origin of eclogites from South Brittany, France: A Sm-Nd isotopic and REE study: Chemical Geology (Isotope Geoscience Section), v. 52, p. 185201.

Boyd, S.R., Hall, A., and Pillinger, C.T., 1993, The measurement of $\delta^{15} \mathrm{~N}$ in crustal rocks by static vacuum mass spectrometry: Application to the origin of the ammonium in the Cornubian batholith, southwest England: Geochimica et Cosmochimica Acta, v. 57, p. 1339-1347.

Breeding, C.M., Ague, J.J., and Bröcker, M., 2004, Fluid-metasedimentary rock interactions in subduction-zone mélange: Implications for the chemical composition of arc magmas: Geology, v. 32, p. 1041-1044. 
591 Busigny, V., and Bebout, G. E., 2013, Nitrogen in the Silicate Earth: Speciation and isotopic behavior during mineral-fluid interactions: Elements, v. 9, p. 353-358.

Busigny, V., Cartigny, P., Philippot, P., Ader, M., and Javoy, M., 2003, Massive recycling of nitrogen and other fluid-mobile elements $(\mathrm{K}, \mathrm{Rb}, \mathrm{Cs}, \mathrm{H})$ in a cold slab environment: evidence from HP to UHP oceanic metasediments of the Schistes Lustrés nappe (western Alps, Europe): Earth and Planetary Science Letters, v. 215, p. 27-42.

Busigny, V., Cartigny, P., and Philippot, P., 2011, Nitrogen isotopes in ophiolitic metagabbros: A re-evaluation of modern nitrogen fluxes in subduction zones and implication for the early Earth atmosphere: Geochimica et Cosmochimica Acta, v. 75, p. 7502-7521.

Busigny, V., Laverne, C., and Bonifacie M., 2005, Nitrogen content and isotopic composition of oceanic crust at a superfast spreading ridge: A profile in altered basalts from ODP Site 1256, Leg 206: Geochemistry Geophysics Geosystems, v. 6, Q12O01, doi:10.1029/2005GC001020.

Dauphas, N., and Marty, B., 1999, Heavy nitrogen in carbonatites of the Kola Peninsula: A possible signature of the deep mantle: Science, v. 286, p. 2488-2490.

Elkins, L. J., Fischer, T. P., Hilton, D. R., Sharp, Z. D., McKnight, S., and Walker, J., 2006, Tracing nitrogen in volcanic and geothermal volatiles from the Nicaraguan volcanic front. Geochimica et Cosmochimica Acta, v. 70, p. 5215-5235.

Eugster, H.P., and Munoz, J., 1966, Ammonium micas: possible sources of atmospheric ammonia and nitrogen: Science, v. 151, p. 683-686.

Gao, J., and Klemd, R., 2001, Primary fluids entrapped at blueschist to eclogite transition: evidence from the Tianshan meta-subduction complex in northwest China: Contributions to Mineralogy and Petrology, v. 142, p. 1-14.

Gao, J., and Klemd, R., 2003, Formation of HP-LT rocks and their tectonic implications in the western Tianshan orogen, NW China; geochemical and age constraints: Lithos, v. 66, p. 1-22.

Gao, J., John, T., Klemd, R., and Xiong, X., 2007, Mobilization of Ti-Nb-Ta during subduction: 623 Gao, J., Long, L.L., Klemd, R., Qian, Q., Liu, D.Y., Xiong, X.M., Su, W., Wang, Y.T., and Yang, evidence from rutile-bearing dehydration segregations and veins hosted in eclogite, Tianshan, NW China: Geochimica et Cosmochimica Acta, v. 71, p. 4974-4996.

Gao, J., Klemd, R., Zhang, L., Wang, Z., and Xiao, X., 1999, P-T path of high-pressure/lowtemperature rocks and tectonic implications in the western Tian Shan mountains, NW China: Journal of metamorphic Geology, v. 17, p. 621-636.

Gao, J., Li, M., He, G., and Xiao, X., 1998, Paleozoic tectonic evolution of the Tianshan Orogen, northwestern China: Tectonophysics, v. 287, p. 213-231.

F.Q., 2009, Tectonic evolution of the South Tianshan orogen and adjacent regions, NW China: 
geochemical and age constraints of granitoid rocks: International Journal of Earth Sciences, v. 98, p. 1221-1238.

Godard, G., 2009, Two orogenic cycles recorded in eclogite-facies gneiss from the southern Armorican Massif (France), European Journal of Mineralogy, v. 21, p. 1173-1190.

Haendel, D., Mühle, K., Nitzsche, H.-M., Stiehl, G., and Wand, U., 1986, Isotopic variations of the fixed nitrogen in metamorphic rocks: Geochimica et Cosmochimica Acta, v. 50, p. 749-758.

Halama, R., Bebout, G.E., John, T., and Schenk, V., 2010, Nitrogen recycling in subducted oceanic lithosphere: The record in high- and ultrahigh-pressure metabasaltic rocks: Geochimica et Cosmochimica Acta, v. 74, p. 1636-1652.

Halama, R., Bebout, G.E., John, T., and Scambelluri, M., 2014, Nitrogen recycling in subducted mantle rocks and implications for the global nitrogen cycle: International Journal of Earth Sciences, v. 103, p. 2081-2099.

Halama, R., John, T., Herms, P., Hauff, F., and Schenk, V., 2011, A stable (Li, O) and radiogenic (Sr, Nd) isotope perspective on metasomatic processes in a subducting slab: Chemical Geology, v. 281 , p. 151-166.

Hall, A., 1987, The ammonium content of Caledonian granites: Journal of the Geological Society of London, 144, 671-674.

Hanschmann, G., 1981, Berechnung von Isotopieeffekten auf quantenchemischer Grundlage am Beispiel stickstoffhaltiger Moleküle: ZFI-Mitteilungen, v. 41, v. 19-31.

Honma, H., and Itihara, Y., 1981, Distribution of ammonium in minerals of metamorphic and granitic rocks: Geochimica et Cosmochimica Acta, v. 45, p. 983-988.

Jia, Y., 2006, Nitrogen isotope fractionations during progressive metamorphism: A case study from the Paleozoic Cooma metasedimentary complex, southeastern Australia: Geochimica et

John, T., Scambelluri, M., Frische, M., Barnes, J.D., and Bach, W., 2011, Dehydration of subducting serpentinite: Implications for halogen mobility in subduction zones and the deep Cosmochimica Acta, v. 70, p. 5201-5214.

John, T., Gussone, N., Podladchikov, Y.Y., Bebout, G.E., Dohmen, R., Halama, R., Klemd, R., Magna, T., and Seitz, H.-M., 2012, Volcanic arcs fed by rapid pulsed fluid flow through subducting slabs: Nature Geoscience, v. 5, p. 489-492.

John, T., Klemd, R., Gao, J., and Garbe-Schönberg, C.D., 2008, Trace-element mobilization in slabs due to non steady-state fluid-rock interaction: constraints from an eclogite-facies transport vein in blueschist (Tianshan, China): Lithos, v. 103, p. 1-24. halogen cycle: Earth and Planetary Science Letters, v. 308, p. 65-76. 
John, T., Scherer, E.E., Haase, K., and Schenk, V., 2004, Trace element fractionation during fluidinduced eclogitization in a subducting slab: trace element and Lu-Hf-Sm-Nd isotope systematics: Earth and Planetary Science Letters, v. 227, p. 441-456.

Johnson, B., and Goldblatt, C., 2015, The nitrogen budget of Earth: Earth-Science Reviews, v. 148, p. $150-173$.

Klemd, R., Schröter, F.C., Will, T.M., and Gao, J., 2002, P-T evolution of glaucophane-omphacite bearing HP-LT rocks in the western Tianshan Orogen, NW China; new evidence for Alpine-type tectonics: Journal of metamorphic Geology, v. 20, p. 239-254.

Klemd, R., Bröcker, M., Hacker, B.R., Gao, J., Gans, P., and Wemmer, K., 2005, New age constraints on the metamorphic evolution of the high-pressure/low-temperature belt in the western Tianshan mountains, NW China: Journal of Geology, v. 113, p. 157-168.

Klemd, R., John, T., Scherer, E.E., Rondenay, S., and Gao, J., 2011, Change in dip of subducting slabs at greater depths: petrological and geochronological evidence from HP-UHP rocks (Tianshan, NW-China): Earth and Planetary Science Letters, v. 310, p. 9-20.

Konrad-Schmolke, M., and Halama, R., 2014, Combined thermodynamic-geochemical modeling in metamorphic geology: Boron as tracer of fluid-rock interaction: Lithos, v. 208-209, p. 393-414.

Li, L., and Bebout, G. E., 2005, Carbon and nitrogen geochemistry of sediments in the Central American convergent margin: Insights regarding subduction input fluxes, diagenesis, and paleoproductivity: Journal of Geophysical Research, v. 110 (B11202), doi:10.1029/2004JB003276.

Li, L., Bebout, G. E., and Idleman, B. D., 2007, Nitrogen concentration and $\delta^{15} \mathrm{~N}$ of altered oceanic crust obtained on ODP Legs 129 and 185: Insights into alteration-related nitrogen enrichment and the nitrogen subduction budget: Geochimica et Cosmochimica Acta, v. 71, p. 2344-2360.

Li, L., Zheng, Y.-F., Cartigny, P., and Li, J., 2014, Anomalous nitrogen isotopes in ultrahighpressure metamorphic rocks from the Sulu orogenic belt: Effect of abiotic nitrogen reduction during fluid-rock interaction: Earth and Planetary Science Letters, v. 403, p. 67-78.

Lü, Z., Zhang, L., Du, J., and Bucher, K., 2008, Coesite inclusions in garnet from eclogitic rocks in western Tianshan, northwest China: Convincing proof of UHP metamorphism: American Mineralogist, v. 93, p. 1845-1850.

Lü, Z., Zhang, L., Du, J., and Bucher, K., 2009, Petrology of coesite-bearing eclogite from Habutengsu Valley, western Tianshan, NW China and its tectonometamorphic implication: Journal of metamorphic Geology, v. 27, p. 773-787. 
Marschall, H.R., Altherr, R., and Rüpke, L., 2007a, Squeezing out the slab - modelling the release of $\mathrm{Li}, \mathrm{Be}$ and $\mathrm{B}$ during progressive high-pressure metamorphism: Chemical Geology, v. 239, p. 323-335.

Marschall, H.R., Pogge von Strandmann, P.A.E., Seitz, H.-M., Elliott, T., and Niu, Y., 2007b, The lithium isotopic composition of orogenic eclogites and deep subducted slabs: Earth and Planetary Science Letters, v. 262, p. 563-580.

Marty, B., and Dauphas, N., 2003, The nitrogen record of crust-mantle interaction and mantle convection from Archean to Present: Earth and Planetary Science Letters, v. 206, p. 397-410.

Matte, P., 2001, The Variscan collage and orogeny (480-290 Ma) and the tectonic definition of the Armorica microplate: a review: Terra Nova, v. 13, p. 122-128.

Mauler, A., Godard, G., and Kunze, K., 2001, Crystallographic fabrics of omphacite, rutile and quartz in Vendée eclogites (Armorican Massif, France). Consequences for deformation mechanisms and regimes: Tectonophysics, v. 342, p. 81-112.

Melzer, S., and Wunder, B., 2000, Island-arc basalt alkali ratios: Constraints from phengite-fluid partitioning experiments: Geology, v. 28, p. 583-586.

Mikhail, S., and Howell, D., 2016, A petrological assessment of diamond as a recorder of the mantle nitrogen cycle: American Mineralogist, v. 101, p. 780-787.

Mingram, B., and Bräuer, K., 2001, Ammonium concentration and nitrogen isotope composition in metasedimentary rocks from different tectonometamorphic units of the European Variscan Belt: Geochimica et Cosmochimica Acta, v. 65, p. 273-287.

Palya, A.P., Buick, I.S., and Bebout, G.E., 2011, Storage and mobility of nitrogen in the continental crust: Evidence from partially melted metasedimentary rocks, Mt. Stafford, Australia: Chemical Geology, v. 281, p. 211-226.

Pauly, J., Marschall, H.R., Meyer, H.-P., Chatterjee, N., and Monteleone, B., 2016, Prolonged Ediacaran-Cambrian metamorphic history and short-lived high-pressure granulite-facies metamorphism in the H.U. Sverdrupfjella, Dronning Maud Land (East Antarctica): Evidence for continental collision during Gondwana assembly: Journal of Petrology, v. 57, p. 185-228.

Peucat, J.J., Vidal, P., Godard, G., and Postaire, B., 1982, Precambrian U-Pb zircon ages in eclogites and garnet pyroxenites from South Brittany (France): an old oceanic crust in the West European Hercynian belt? Earth and Planetary Science Letters, v. 60, p. 70-78.

Philippot, P., Busigny, V., Scambelluri, M., and Cartigny, P., 2007, Oxygen and nitrogen isotopes as tracers of fluid activities in serpentinites and metasediments during subduction: Mineralogy and Petrology, v. 91, p. 11-24. 
723 Pitcairn, I.K., Teagle, D.A.H., Kerrich, R., Craw, D., and Brewer, T.S., 2005, The behavior of 724 nitrogen and nitrogen isotopes during metamorphism and mineralization: Evidence from the Otago and Alpine Schists, New Zealand: Earth and Planetary Science Letters, v. 233, p. 229-246.

Putnis, A., and Austrheim, H., 2010, Fluid-induced processes: metasomatism and metamorphism: Geofluids, v. 10, p. 254-269.

Putnis, A., and John, T., 2010, Replacement processes in the Earth's Crust: Elements, v. 6, p. 159164.

Sadofsky S. J., and Bebout, G. E., 2000, Ammonium partitioning and nitrogen-isotope fractionation among coexisting micas during high-temperature fluid-rock interactions: Examples from the New England Appalachians: Geochimica et Cosmochimica Acta, v. 64, p. 2835-2849.

Sadofsky, S.J., and Bebout, G.E., 2003, Record of forearc devolatilization in low-T, high-P/T metasedimentary suites: Significance for models of convergent margin chemical cycling: Geochemistry Geophysics Geosystems, v. 4, 9003, doi:10.1029/2002GC000412.

Sadofsky, S. J., and Bebout, G. E., 2004, Nitrogen geochemistry of subducting sediments: New results from the Izu-Bonin-Mariana margin and insights regarding global nitrogen subduction: Geochemistry Geophysics Geosystems, v. 5, Q03I15, doi:10.1029/2003GC000543.

Şengör, A.C., Natal'in, B.A., and Burtman, V.S., 1993, Evolution of the Altaid tectonic collage and Palaeozoic crustal growth in Eurasia: Nature, v. 364, p. 299-306.

Şengör, A.C., and Natal'in, B.A., 1996, Paleotectonics of Asia: fragments of a synthesis, in: Yin, A., and Harrison, M., eds., The tectonic evolution of Asia: Cambridge University Press, Cambridge, p. $486-640$.

Sievers, N.E., Tenore, J., Bebout, G.E., and Penniston-Dorland, S.C., 2016, Fingerprints of forearc element mobility in blueschist-facies metaconglomerates, Catalina Schist, California: International Geology Review (this issue).

Sorensen, S.S., Grossman, J.N., and Perfit, M.R., 1997, Phengite-hosted LILE enrichment in eclogite and related rocks: Implications for fluid-mediated mass transfer in subduction zones and arc magma genesis: Journal of Petrology, v. 38, p. 3-34.

Spandler, C., and Pirard, C., 2013, Element recycling from subducting slabs to arc crust: A review: Lithos, v. 170-171, p. 208-223.

Su, W., Gao, J., Klemd, R., Li, J.L., Zhang, X., Li, X.H., Chen, N.S., and Zhang, L., 2010, U-Pb zircon geochronology of Tianshan eclogites in NW China: implication for the collision between the Yili and Tarim blocks of the southwestern Altaids: European Journal Mineralogy, v. 22, p. $473-478$. 
Svensen, H., Bebout, G., Kronz, A., Li, L., Planke, S., Chevallier, L., and Jamtveit, B., 2008, Nitrogen geochemistry as a tracer of fluid flow in a hydrothermal vent complex in the Karoo Basin, South Africa. Geochimica et Cosmochimica Acta, v. 72, p. 4929-4947.

Tian, Z.L., and Wei, C.J., 2013, Metamorphism of ultrahigh-pressure eclogites from the Kebuerte Valley, South Tianshan, NW China: phase equilibria and P-T path: Journal of metamorphic Geology, v. 31, p. 281-300.

Valley, J.W., 1986, Stable isotope geochemistry of metamorphic rocks: Reviews in Mineralogy, v. 16, p. 445-489.

van der Straaten, F., Halama, R., John, T., Schenk, V., Hauff, F., and Andersen, N., 2012, Tracing the effects of high-pressure metasomatic fluids and seawater alteration in blueschist-facies overprinted eclogites: Implications for subduction channel processes: Chemical Geology, v. 292293, p. 69-87.

van der Straaten F., Schenk V., John T., and Gao J., 2008, Blueschist-facies rehydration of eclogites (Tian Shan, NW-China): implications for fluid-rock interaction in the subduction channel: Chemical Geology, v. 225, p. 195-219.

Watenphul, A., Wunder, B., Wirth, R., and Heinrich, W., 2010, Ammonium-bearing clinopyroxene: A potential nitrogen reservoir in the Earth's mantle: Chemical Geology, v. 270, p. 240-248.

Wei, C., Wang, W., Clarke, G.L., Zhang, L., and Song, S., 2009, Metamorphism of high/ultrahighpressure pelitic-felsic schist in the South Tianshan orogen, NW China: Phase equilibria and P-T path: Journal of Petrology, v. 50, p. 1973-1991.

Windley, B.F., Allen, M.B., Zhang, C., Zhao, Z.-Y., and Wang, G.-R., 1990, Paleozoic accretion and Cenozoic redeformation of the Chinese Tien Shan Range, central Asia: Geology, v. 18, p. $128-131$.

Zack, T., and John, T., 2007, An evaluation of reactive fluid flow and trace element mobility in subducting slabs: Chemical Geology, v. 239, p. 199-216.

Zack, T., Rivers, T., and Foley, S.F., 2001, Cs-Rb-Ba systematics in phengite and amphibole: an assessment of fluid mobility at $2.0 \mathrm{GPa}$ in eclogites from Trescolmen, Central Alps: Contributions to Mineralogy and Petrology, v. 140, p. 651-669. 


\section{Figure captions}

Figure 1:

787 Locations and geological setting of the sampling areas. A) Simplified geological map of the 788 Chinese South Tianshan (modified after Gao et al. 1999). B) Geological map showing the Les Essarts HP unit in the Southern Armorican Massif, France (modified after Mauler et al. 2001).

Figure 2:

792 Sketches and field photographs illustrating the sample profiles for $\mathbf{A}$ ) the prograde blueschist793 eclogite transition (JTS sequence; Beinlich et al. 2010) and B) the retrograde eclogite-blueschist 794 transition (FTS sequence; van der Straaten et al. 2012). C) shows a map of the La Gerbaudière 795 quarry (Saint-Philbert-de Bouaine, Vendée) in 1999 with location of the sampling traverse 796 (modified after Mauler et al. 2001 and Godard 2001).

Figure 3:

799 Nitrogen elemental and isotopic variations in A) the prograde blueschist-eclogite transition (JTS 800 sequence, Tianshan) and B) the gneiss-eclogite traverse (Vendée). Additional trace element data for 801 the JTS sequence are from Beinlich et al. (2010), with a precision of $<5 \%$ RSD (John et al. 2008; van der Straaten et al. 2012). Uncertainties for element concentrations are smaller than the symbol size.

804

Figure 4:

806 Elemental correlations of $\mathrm{N}$ with other trace elements in the three profiles studied. A) JTS sequence, 807 Tianshan, B) FTS sequence, Tianshan, C) Gneiss-eclogite traverse, Vendée.

\section{Figure 5:}

810 Modal content of white mica (phengite + paragonite) in rocks of the prograde blueschist-eclogite 811 transition (JTS traverse, Tianshan; data from Beinlich et al. 2010) plotted versus the $\mathrm{N}$ 812 concentrations.

\section{Figure 6:}

815 Nitrogen elemental and isotopic systematics of the analysed rocks compared to fresh MORB 816 (Busigny et al. 2005), eclogites (Halama et al. 2010), metasedimentary rocks (Bebout and Fogel 817 1992; Mingram and Bräuer 2001; Busigny et al. 2003) and altered oceanic crust (AOC; Busigny et 
818

819

820

821

822

823

824

825

826

827

828

829

830

831

832

833

834

835

836

837

838

839

840

841

842

843

844

845

846

847

848

849

850

al. 2005; Li et al. 2007). Colours of individual symbols are the same as in Figures 2 (JTS and FTS traverses) and $3 b$ (Vendée traverse).

\section{Figure 7:}

Metamorphic dehydration models. A) Batch devolatilization (solid lines) and Rayleigh distillation (dashed lines) models of $\mathrm{N}$ isotopic compositions and concentrations, using the most $\mathrm{N}$-rich blueschist of the JTS sequence (JTS-A) as initial composition. Isotopic fractionation by batch devolatilization is described by the equation $\delta^{15} \mathrm{~N}_{\mathrm{f}}=\delta^{15} \mathrm{~N}_{\mathrm{i}}-(1-\mathrm{F}) 1000 \ln \alpha$, and fractionation following Rayleigh distillation is given by the equation $\delta^{15} \mathrm{~N}_{\mathrm{f}}=\delta^{15} \mathrm{~N}_{\mathrm{i}}+1000\left(\mathrm{~F}^{(-1)}-1\right)$, where $\delta^{15} \mathrm{~N}_{\mathrm{i}}$ and $\delta^{15} \mathrm{~N}_{\mathrm{f}}$ and are the initial and final isotopic compositions of the rock, $\alpha$ is the fluid-rock fractionation factor and $\mathrm{F}$ is the $\mathrm{N}$ fraction that remains in the rock after devolatilization. Fractionation factors used in the calculations are those tabulated in Haendel et al. (1986) based on Hanschmann (1981) for $527^{\circ} \mathrm{C}$. Tick marks give the fraction of $\mathrm{N}$ remaining in the rock in $10 \%$ steps. B) and C) show calculated curves of progressive phengite dehydration by Rayleigh distillation using equations and methodology outlined in Busigny et al. (2003) and exchange coefficients $\left(\mathrm{K}_{\mathrm{D}}\right.$ values) based on experimental conditions of $2.0 \mathrm{GPa}$ and $600{ }^{\circ} \mathrm{C}$ (Melzer and Wunder 2000), which represent a good approximation of the natural peak P-T conditions. Rayleigh distillation is modelled by fixing the initial composition and applying $\mathrm{K}_{\mathrm{D}}{ }^{\mathrm{Cs}-\mathrm{N}}=0.14$ and $\mathrm{K}_{\mathrm{D}}{ }^{\mathrm{Cs}-\mathrm{Rb}}=$ 0.14. Tick marks give the fraction of remaining phengite after dehydration in $10 \%$ steps.

\section{Figure 8:}

Relationships between $\mathrm{N}, \delta^{15} \mathrm{~N}$ and $\mathrm{Pb}, \mathrm{CaO}$ in the prograde blueschist-eclogite JTS sequence. The grey band indicates the average $\delta^{15} \mathrm{~N}$ value of the 9 samples from the profile, excluding the vein $\left(\delta^{15} \mathrm{~N}_{\text {average }}=+2.1 \pm 0.3\right)$.

\section{Figure 9:}

Potential mixing relationships in $\delta^{15} \mathrm{~N}-\mathrm{Rb} / \mathrm{N}$ and $\delta^{15} \mathrm{~N}-\mathrm{K} / \mathrm{N}$ space for the Tian Shan profiles (A) and the Vendée profile (B). The field for altered oceanic crust (AOC) is based on data from the East Pacific Rise (EPR; Busigny et al. 2005). Compositions of (meta)sedimentary rocks are average values from five distinct locations (data from Busigny et al. 2003; Sadofsky and Bebout 2003, 2004; Li and Bebout 2005). Solid lines are calculated mixing curves with 10\% tick marks.

\section{Figure 10:}


851 Summary figure illustrating the processes observed in the metamorphosed mafic rock sequences of 852 this study. 
A) Tianshan

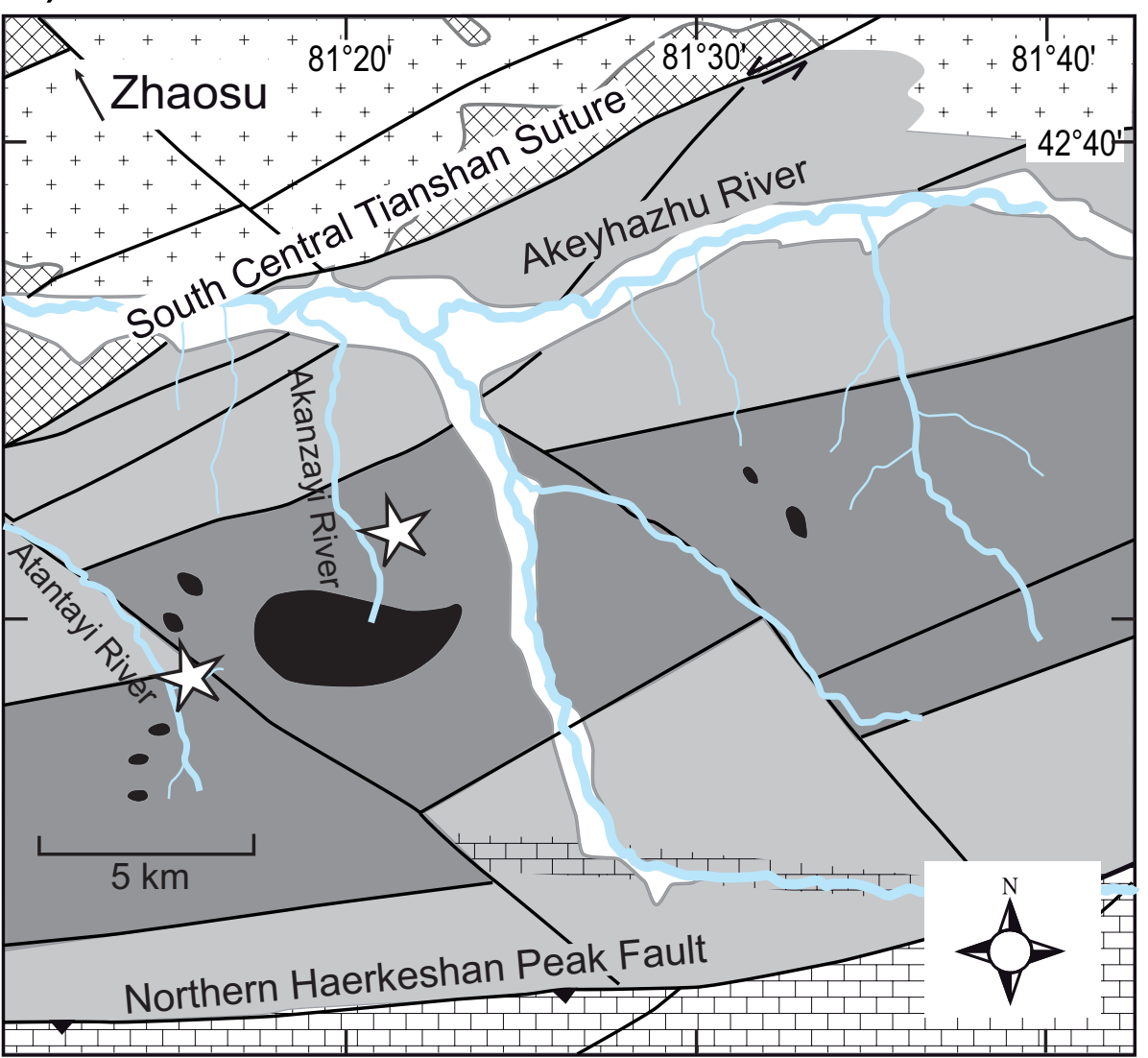

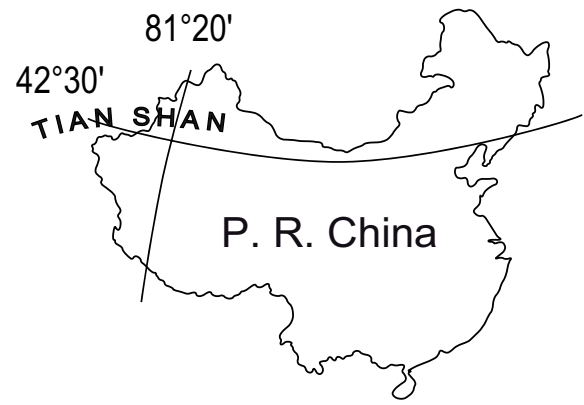

Sample locations

Alluvium

Precambrian amphibolitefacies rocks

Marble

Granite

Greenschist-facies rocks, undifferentiated

Blueschist-facies rocks, undifferentiated

Eclogite

\section{B) South Armorican Massif}

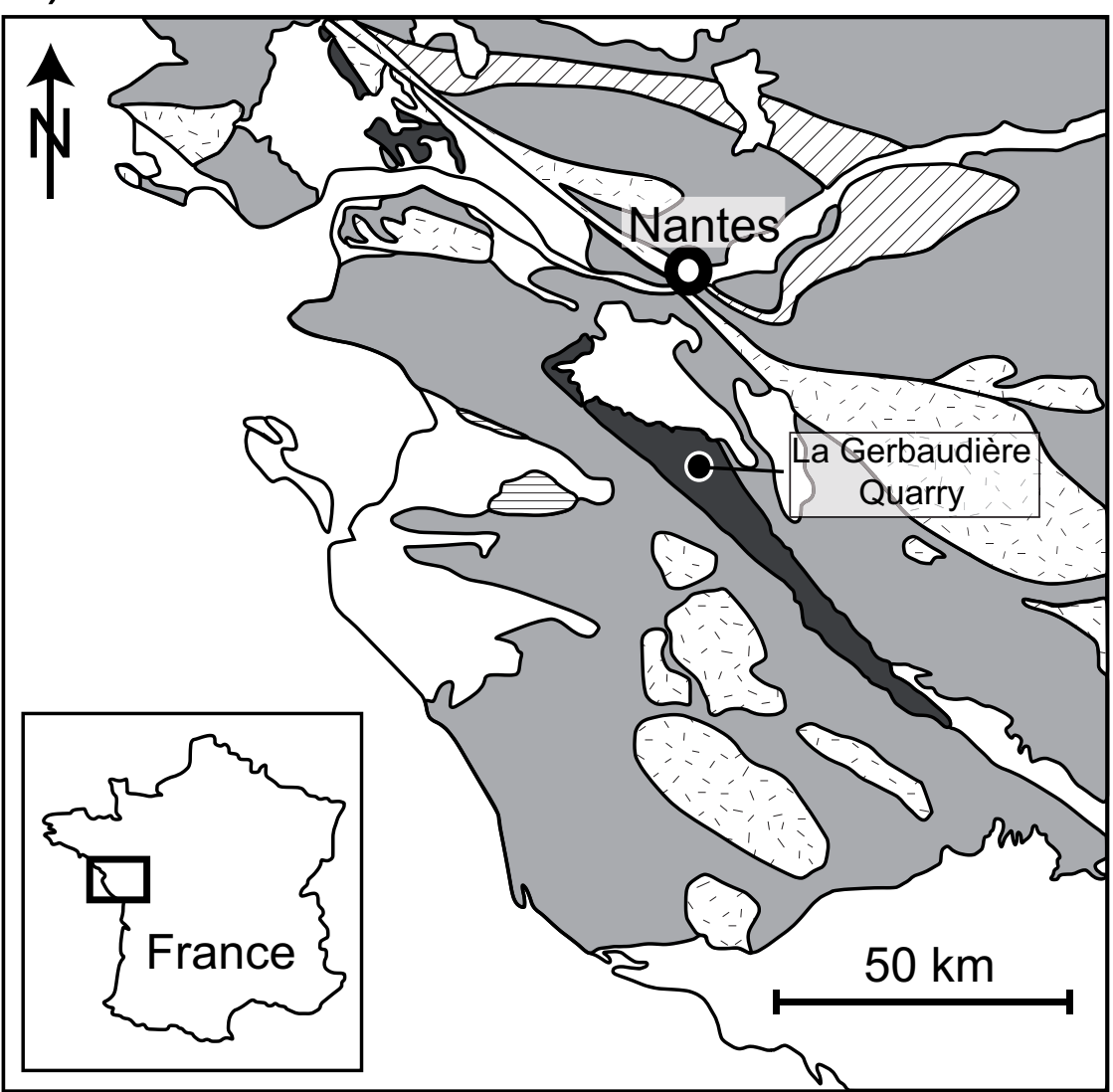

$\square$ Post-Variscan sediments

$\therefore$ Variscan granites

QA Champtoceaux HP unit

Les Essarts HP unit

Bois-de-Céné blueschist unit Other metamorphic rocks Sample location 
Fig. 3

A) JTS sequence

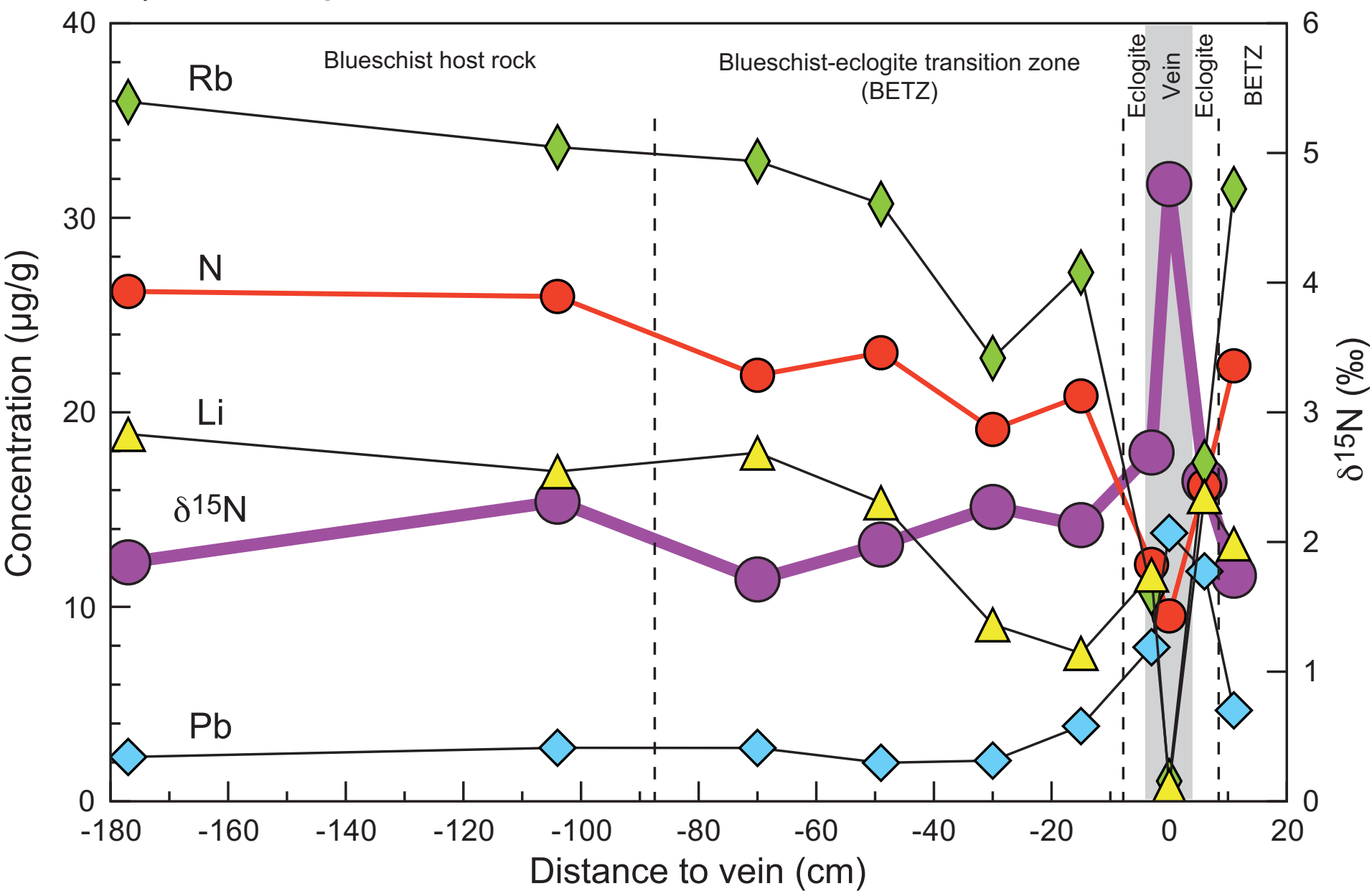

B) Vendée traverse

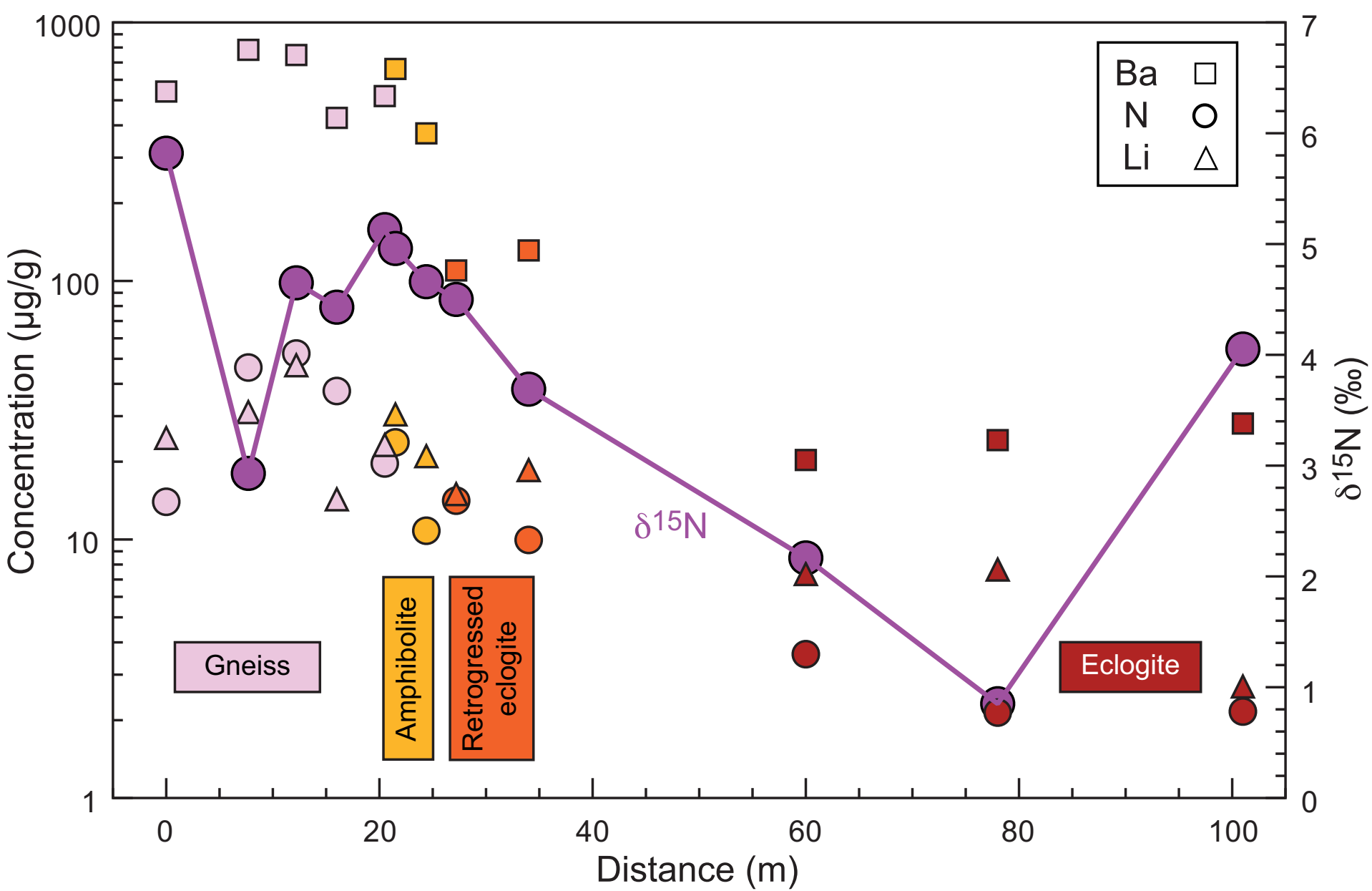


Fig. 5

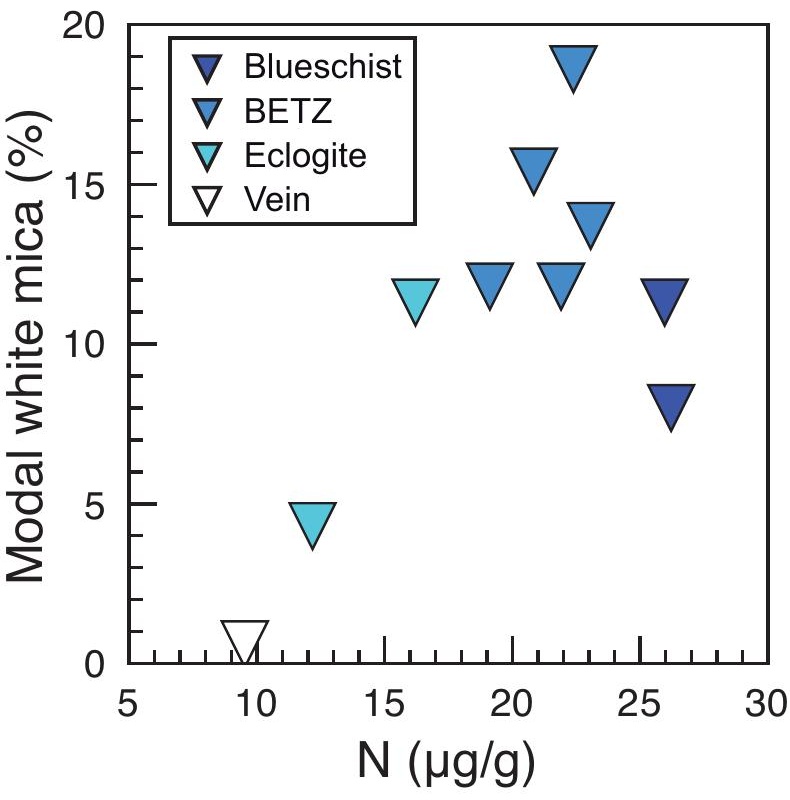


Fig. 6

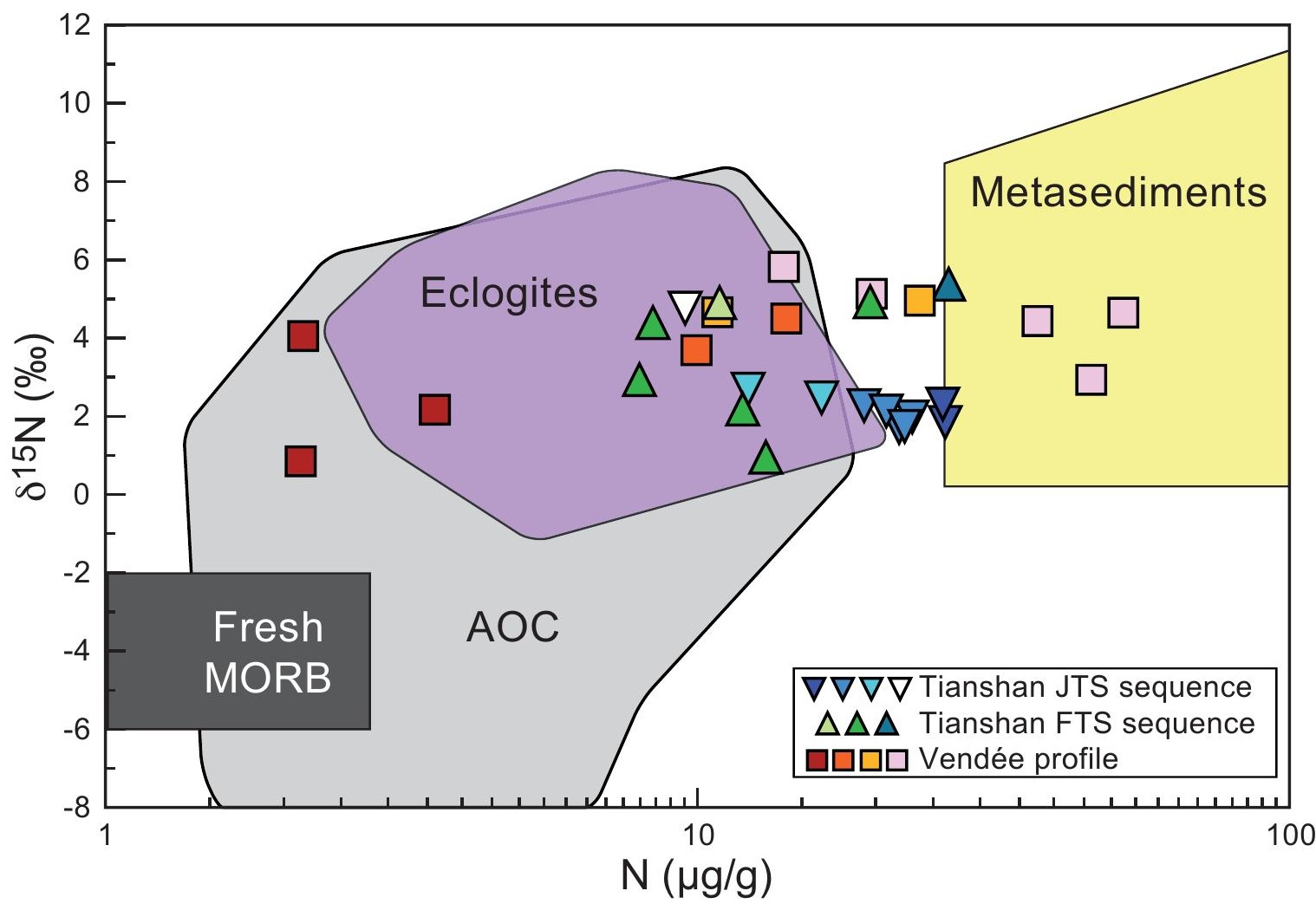


Fig. 10

\section{Phengite growth}

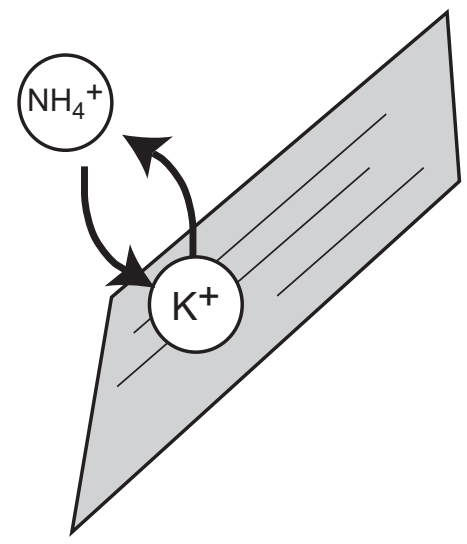

Phengite as major host of nitrogen via incorporation of $\mathrm{NH}_{4}{ }^{+}$for $\mathrm{K}^{+}$

Phengite breakdown

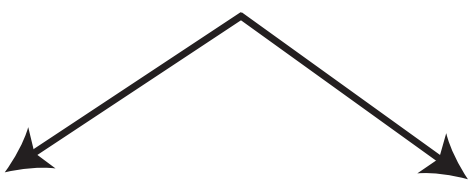

Phengite re-equilibration
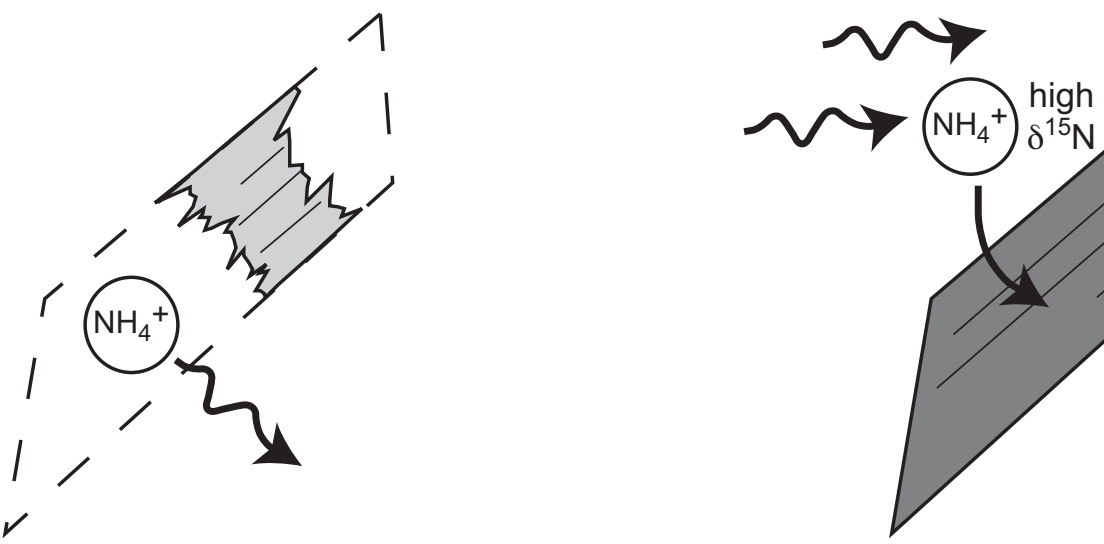

Mobilisation of nitrogen and release into fluid

Exchange with high- $\delta^{15} \mathrm{~N}$ sediment-derived fluid 
Table 1: Nitrogen concentration and isotope data of the three profiles investigated in this study

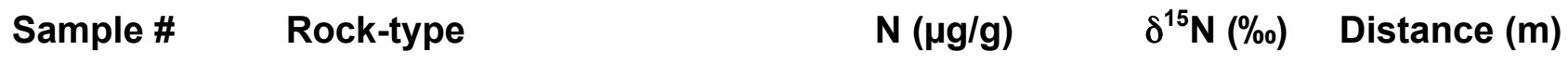

Tian Shan, prograde blueschist-eclogite transformation:

$\begin{array}{llllr}\text { JTS-A } & \text { blueschist } & 26.2 & 1.8 & -1.77 \\ \text { JTS-B } & \text { blueschist } & 26.0 & 2.3 & -1.04 \\ \text { JTS-C } & \text { bs/ec } & 21.9 & 1.7 & -0.70 \\ \text { JTS-D } & \text { bs/ec } & 23.1 & 2.0 & -0.49 \\ \text { JTS-E } & \text { bs/ec } & 19.1 & 2.3 & -0.30 \\ \text { JTS-F } & \text { bs/ec } & 20.8 & 2.1 & -0.15 \\ \text { JTS-G } & \text { eclogite } & 12.2 & 2.7 & -0.03 \\ \text { JTS-D' } & \text { qz-carbonate vein } & 9.5 & 4.8 & 0 \\ \text { JTS-I } & \text { eclogite } & 16.2 & 2.5 & 0.06 \\ \text { JTS-J } & \text { bs/ec } & 22.4 & 1.7 & 0.11\end{array}$

Tian Shan, retrograde eclogite-blueschist transformation (FTS 9-1 sequence)

\begin{tabular}{|c|c|c|c|c|}
\hline FTS 9.1-1 & blueschist & 26.6 & 5.38 & 0 \\
\hline FTS 9.1-2 & ec/bs & 13.1 & 0.96 & 0.05 \\
\hline FTS 9.1-3 B & ec/bs & 19.6 & 4.93 & 0.10 \\
\hline FTS $9.1-3 \mathrm{~A}$ & ec/bs & 11.9 & 2.19 & 0.10 \\
\hline FTS 9.1-4 & ec/bs & 8.0 & 2.94 & 0.15 \\
\hline FTS 9.1-5 B & ec/bs & 8.4 & 4.40 & 0.20 \\
\hline FTS 9.1-5 A & eclogite & 10.9 & 4.91 & 0.20 \\
\hline \multicolumn{5}{|c|}{ Vendée, gneiss-to-eclogite profile } \\
\hline G08-3-2 & gneiss & 14.0 & 5.8 & 0 \\
\hline G08-3-1 & biotite gneiss & 46.3 & 2.9 & 7.7 \\
\hline G08-3-3 & garnet gneiss & 52.4 & 4.6 & 12.2 \\
\hline G08-3-4 & garnet gneiss & 37.5 & 4.4 & 16.0 \\
\hline G08-3-5 & gneiss & 19.7 & 5.1 & 20.5 \\
\hline G08-3-6 & garnet amphibolite & 23.7 & 5.0 & 21.5 \\
\hline G08-3-7 & garnet amphibolite & 10.8 & 4.7 & 24.4 \\
\hline G08-3-8 & retrogressed eclogite & 14.1 & 4.5 & 27.2 \\
\hline G08-3-9 & retrogressed eclogite & 10.0 & 3.7 & 34 \\
\hline G08-3-10 & eclogite & 3.6 & 2.2 & 60 \\
\hline G08-3-11 & eclogite & 2.1 & 0.9 & 78 \\
\hline G08-3-12 & eclogite & 2.3 & 4.5 & 101 \\
\hline G08-3-12 repl. & eclogite & 2.1 & 3.6 & 101 \\
\hline G08-3-12 avg. & eclogite & 2.2 & 4.1 & 101 \\
\hline
\end{tabular}

repl. = replicate analyses; avg. = average 


\begin{tabular}{|c|c|c|c|c|c|c|c|c|c|c|c|c|c|c|c|c|c|}
\hline Sample & JTS-A & JTS-B & JTS-C & JTS-D & JTS-E & JTS-F & JTS-J & JTS-G & JTS-I & JTS-D' & FTS 9-1.1 & FTS 9-1.2 & FTS 9-1.3B & FTS 9-1.3A & FTS 9-1.4 & FTS 9-1.5B & FTS 9-1.5A \\
\hline Traverse & JTS & JTS & JTS & JTS & JTS & JTS & JTS & JTS & JTS & JTS & FTS & FTS & FTS & FTS & FTS & FTS & FTS \\
\hline Rock type & Blueschist & Blueschist & $\mathrm{EC} / \mathrm{BS}$ & $\mathrm{EC} / \mathrm{BS}$ & $\mathrm{EC} / \mathrm{BS}$ & $\mathrm{EC} / \mathrm{BS}$ & $\mathrm{EC} / \mathrm{BS}$ & Eclogite & Eclogite & Vein & Blueschist & Blueschist & $\mathrm{EC} / \mathrm{BS}$ & $\mathrm{EC} / \mathrm{BS}$ & $\mathrm{EC} / \mathrm{BS}$ & $\mathrm{EC} / \mathrm{BS}$ & Eclogite \\
\hline Location & Host rock & Host rock & BETZ & BETZ & BETZ & BETZ & BETZ & Selvage & Selvage & Vein & Host rock & Host rock & BETZ & BETZ & BETZ & BETZ & Selvage \\
\hline \multicolumn{18}{|c|}{ Major elements (wt.\%) } \\
\hline $\mathrm{SiO}_{2}$ & 47.66 & 48.71 & 47.16 & 49.03 & 48.53 & 41.83 & 49.29 & 45.4 & 53.55 & 52.43 & 47.23 & 39.43 & 36.43 & 42.03 & 41.17 & 43.65 & 49.75 \\
\hline $\mathrm{TiO}_{2}$ & 3.76 & 3.55 & 3.54 & 3.64 & 3.34 & 3.58 & 3.99 & 3.45 & 3.23 & 0.54 & 0.65 & 0.75 & 0.44 & 0.58 & 0.68 & 0.59 & 0.64 \\
\hline $\mathrm{Al}_{2} \mathrm{O}_{3}$ & 15.44 & 14.4 & 14.29 & 14.51 & 14.32 & 14.42 & 14.63 & 11.84 & 12.01 & 4.57 & 13.26 & 12.77 & 9.48 & 12.15 & 12.60 & 11.93 & 12.52 \\
\hline $\mathrm{Fe}_{2} \mathrm{O}_{3}$ & 13.52 & 12.99 & 12.39 & 13.29 & 16.22 & 16.62 & 12.35 & 12.93 & 8.76 & 8.86 & 8.23 & 10.84 & 9.27 & 8.65 & 8.81 & 9.30 & 7.94 \\
\hline $\mathrm{MnO}$ & 0.19 & 0.2 & 0.16 & 0.2 & 0.29 & 0.28 & 0.14 & 0.19 & 0.05 & 0.12 & 0.11 & 0.35 & 0.23 & 0.17 & 0.22 & 0.24 & 0.20 \\
\hline MgO & 5.53 & 5.31 & 5.87 & 4.47 & 3.64 & 4.72 & 4.13 & 4.72 & 3.9 & 4.22 & 10.29 & 10.30 & 12.28 & 11.23 & 9.69 & 9.27 & 7.59 \\
\hline $\mathrm{CaO}$ & 6.04 & 6.83 & 7.68 & 8.07 & 7.98 & 9.56 & 8.54 & 13.11 & 11.62 & 15.15 & 6.66 & 9.86 & 11.90 & 8.67 & 11.12 & 11.72 & 12.28 \\
\hline $\mathrm{Na}_{2} \mathrm{O}$ & 3.25 & 3.01 & 3.46 & 3.19 & 1.95 & 1.86 & 2.96 & 3.04 & 3.76 & 0.19 & 5.56 & 4.10 & 4.16 & 4.88 & 4.78 & 5.09 & 5.94 \\
\hline $\mathrm{K}_{2} \mathrm{O}$ & 2.07 & 1.93 & 1.91 & 1.79 & 1.34 & 1.59 & 1.89 & 0.68 & 1.11 & 0.07 & 0.28 & 0.31 & 0.16 & 0.24 & 0.15 & 0.10 & 0.08 \\
\hline $\mathrm{P}_{2} \mathrm{O}_{5}$ & 0.70 & 0.67 & 0.65 & 0.69 & 0.62 & 0.57 & 0.55 & 0.52 & 0.6 & 2.66 & 0.01 & 0.01 & 0.01 & 0.05 & 0.01 & 0.01 & 0.01 \\
\hline $\mathrm{CO}_{2}$ & n.a. & n.a. & n.a. & n.a. & n.a. & n.a. & n.a. & n.a. & n.a. & n.a. & 7.34 & 11.76 & n.a. & 11.48 & 10.94 & 8.80 & 3.37 \\
\hline $\mathrm{H}_{2} \mathrm{O}=\mathrm{LOI}-\mathrm{CO}_{2}$ & n.a. & n.a. & n.a. & n.a. & n.a. & n.a. & n.a. & n.a. & n.a. & n.a. & 1.68 & 0.47 & n.a. & 1.34 & 0.50 & 0.34 & 0.10 \\
\hline LOI & 1.01 & 1.84 & 2.16 & 0.29 & 0.7 & 3.96 & 0.48 & 3.67 & 0.67 & 11.94 & 9.02 & 12.23 & 17.61 & 12.82 & 11.44 & 9.14 & 3.47 \\
\hline Total & 99.17 & 99.44 & 99.27 & 99.17 & 98.93 & 98.99 & 98.95 & 99.55 & 99.26 & 100.75 & 101.30 & 100.95 & 101.97 & 101.47 & 100.67 & 101.04 & 100.42 \\
\hline \multicolumn{18}{|c|}{ Trace elements $(\mu g / g)$} \\
\hline Li & 20.4 & 18.8 & 19.2 & 16.3 & 10.0 & 8.21 & 14.3 & 12.8 & 16.9 & 0.781 & 42.3 & 30.2 & 32.0 & 124 & 35.5 & 33.6 & 37.7 \\
\hline $\mathrm{Rb}$ & 36.0 & 33.6 & 32.9 & 30.7 & 22.8 & 27.2 & 31.5 & 10.7 & 17.4 & 1.04 & 5.70 & 6.25 & 3.09 & 4.81 & 2.31 & 1.67 & 1.65 \\
\hline $\mathrm{Sr}$ & 205 & 278 & 315 & 207 & 269 & 608 & 364 & 859 & 1117 & 2132 & 301 & 412 & 496 & 448 & 412 & 316 & 159 \\
\hline Y & 49.0 & 47.7 & 36.7 & 47.6 & 78.6 & 55.0 & 49.6 & 37.9 & 37.6 & 27.7 & 13.2 & 38.6 & 15.4 & 13.8 & 22.2 & 16.0 & 18.4 \\
\hline $\mathrm{Zr}$ & 382 & 333 & 340 & 311 & 303 & 301 & 342 & 290 & 279 & 36.3 & 26.7 & 28.6 & 16.2 & 22.7 & 26.7 & 23.5 & 26.2 \\
\hline Cs & 0.790 & 0.755 & 0.733 & 0.685 & 0.518 & 0.635 & 0.718 & 0.261 & 0.409 & 0.03 & 0.25 & 0.30 & 0.29 & 0.38 & 0.16 & 0.17 & 0.14 \\
\hline Ba & 603 & 574 & 570 & 539 & 401 & 481 & 583 & 189 & 318 & 20.1 & 102 & 120 & 65.7 & 92.8 & 49.7 & 34.1 & 30.5 \\
\hline $\mathrm{Pb}$ & 2.28 & 2.75 & 2.74 & 1.98 & 2.09 & 3.87 & 4.68 & 7.92 & 11.8 & 13.8 & 3.16 & 3.85 & 4.39 & 4.43 & 3.68 & 2.64 & 1.52 \\
\hline \multicolumn{18}{|c|}{ Modal composition } \\
\hline Garnet & 22.8 & 22.3 & 18.3 & 24.9 & 31.3 & 23.6 & 16.3 & 16.0 & 10.0 & 24.6 & & & & & & & \\
\hline Omphacite & 16.9 & 17.5 & 29.7 & 34.1 & 30.9 & 26.9 & 39.5 & 50.0 & 50.0 & 5.0 & & & & & & & \\
\hline Glaucophane & 36.4 & 28.2 & 23.8 & 6.4 & 2.8 & 1.0 & 0.3 & 0.3 & - & 1.5 & & & & & & & \\
\hline White mica & 8.0 & 11.3 & 11.8 & 13.7 & 11.8 & 15.4 & 18.6 & 4.3 & 11.3 & 0.6 & & & & & & & \\
\hline Quartz & 2.4 & 2.8 & 1.7 & 7.5 & 8.7 & 11.5 & 10.0 & 6.0 & 11.6 & 19.0 & & & & & & & \\
\hline Carbonate & 0.9 & 5.2 & 4.7 & 0.9 & 2.6 & 12.1 & 0.7 & 7.3 & 1.7 & 38.0 & & & & & & & \\
\hline Others & 12.7 & 12.6 & 10.0 & 12.5 & 11.9 & 9.5 & 14.6 & 15.9 & 15.4 & 11.3 & & & & & & & \\
\hline
\end{tabular}


Sample

Rock type

Traverse distance ( $\mathrm{m}$ )

Major elements (wt.\%)

$\mathrm{SiO}_{2}$

$\mathrm{TiO}_{2}$

$\mathrm{Fe}_{2} \mathrm{O}_{3}$

$\mathrm{MnO}$

$\mathrm{MgO}$

$\mathrm{CaO}$

$\mathrm{Na}_{2} \mathrm{O}$

$\mathrm{K}_{2} \mathrm{O}$

$\mathrm{P}_{2} \mathrm{O}_{5}$

Total

Trace elements $(\mu \mathrm{g} / \mathrm{g})$

$\mathrm{Cr}$

$\mathrm{Ni}$

$\mathrm{Ni}$

RetEc $=$ Retrogressed eclogite

b.d.I. = below detection limit
0.0$$
\text { 608-3-1 }
$$

Gneiss

G08-3-3

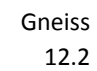

G08-3-4

Gneiss
16.0

G08-3-5
Gneiss

G08-3-6

G08-3-7

20.5

21.5

24.4

G08-3-8

G08-3-9

G08-3-10

Eclogite

G08-3-11

clogite

G08-3-12

73.721 .5

$\begin{array}{rrr}65.16 & 73.59 & 60.19 \\ 0.66 & 0.27 & 1.19 \\ 15.83 & 13.73 & 15.29 \\ 5.38 & 1.85 & 8.17 \\ 0.09 & 0.02 & 0.13 \\ 2.37 & 0.56 & 3.66 \\ 2.22 & 1.17 & 3.04 \\ 3.15 & 3.02 & 1.89 \\ 2.84 & 4.29 & 3.41 \\ 0.20 & 0.10 & 0.19 \\ 1.45 & 0.82 & 2.23 \\ 99.35 & 99.41 & 99.38 \\ & & \\ & & \\ 24.7 & 31.1 & 47.2 \\ 20.3 & \text { b.d.I. } & 72.2 \\ \text { b.d.I. } & \text { b.d.I. } & 5.0 \\ 240 & 142 & 245 \\ 190 & 149 & 241 \\ 540 & 784 & 748\end{array}$

62.96
0.76
15.72
6.78
0.14
2.78
3.03
3.35
1.44
0.16
1.96
99.09


23.2
30.3
3.1
357
244
519

$\begin{array}{rr}63.17 & 54.21 \\ 0.80 & 0.98 \\ 15.29 & 16.74 \\ 6.61 & 8.52 \\ 0.12 & 0.20 \\ 2.67 & 5.63 \\ 2.28 & 7.42 \\ 3.67 & 2.90 \\ 2.04 & 1.00 \\ 0.10 & 0.13 \\ 2.08 & 1.91 \\ 98.83 & 99.63\end{array}$

52.53

0.28
21.73

50.62

0.33
18.99

18.99
6.08

21.73
4.32
0.07

5.04
10.93

2.70

0.88
0.02

1.56

100.06

0.13

7.58

10.87

2.82
0.74
0.02$$
0.02
$$$$
1.78
$$

99.95

48.02

48.86

1.23

14.51
11.82

0.19

1.21
14.73

11.40

0.19

$\begin{array}{ll}7.98 & 8.02\end{array}$

12.40

8.02
11.28

0.11
0.10

0.72

99.25

3.20
0.05

0.10

0.41

99.45

48.16

1.29

15.13
11.68

0.18

8.06

12.17

2.41
0.10

0.10

0.52

99.79

$\begin{array}{rr}14.3 & 23.2 \\ 35.1 & 30.3 \\ 10.2 & 3.1 \\ 258 & 357 \\ 356 & 244 \\ 427 & 519\end{array}$

30.5
42.9
2.8
355
297
661

21.0
169
28.7
281
188
372

15.0
52.7
b.d.I.
813
15.6
110

18.5
147

7.35
258

7.65
202

2.70

1.8
406

14.5

258
59.5

202

215

81.0

31.5
126

80.9

125

89.1 